\title{
Biomaterial-based cell delivery strategies to promote liver regeneration
}

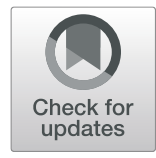

\author{
Maqsood Ali $^{1}$ and Samantha L. Payne ${ }^{2^{*}}$ (D)
}

\begin{abstract}
Chronic liver disease and cirrhosis is a widespread and untreatable condition that leads to lifelong impairment and eventual death. The scarcity of liver transplantation options requires the development of new strategies to attenuate disease progression and reestablish liver function by promoting regeneration. Biomaterials are becoming an increasingly promising option to both culture and deliver cells to support in vivo viability and long-term function. There is a wide variety of both natural and synthetic biomaterials that are becoming established as delivery vehicles with their own unique advantages and disadvantages for liver regeneration. We review the latest developments in cell transplantation strategies to promote liver regeneration, with a focus on the use of both natural and synthetic biomaterials for cell culture and delivery. We conclude that future work will need to refine the use of these biomaterials and combine them with novel strategies that recapitulate liver organization and function in order to translate this strategy to clinical use.
\end{abstract}

\section{Liver cirrhosis}

Normal liver function can be disrupted by many different diseases and injury, such as viruses, drugs, poisons, carcinomas, hemochromatosis, and Wilson disease, resulting in a fibrotic response and eventual cirrhosis [1]. The liver responds to insult in one of two ways, depending on if the damage is acute or chronic. Acute liver injury is primarily caused by viruses and drugs. Although the liver is capable of regeneration in response to acute damage, prolonged insult can result in permanent tissue damage and functional impairment, eventually leading to end-stage liver disease and cirrhosis [1-4]. Cirrhosis of the liver is the end point of chronic liver fibrosis. Worldwide, cirrhosis is the 14th most common cause of death, and the one-year mortality rate is $57 \%$ for end-stage liver fibrosis [5]. From 2004 to 2010, hepatic cirrhosis accounted for more than one million deaths, which is $2 \%$ of deaths worldwide, with an additional 31 million patients living with disabilities [6]. As liver disease

* Correspondence: samantha.payne@tufts.edu

${ }^{2}$ Department of Biomedical Engineering, School of Engineering, Tufts University, Medford, MA 02155, USA

Full list of author information is available at the end of the article progresses, the costs associated with treatment increase. The total annual cost in the USA is estimated at $\$ 17,277$ USD for patients with no cirrhosis, $\$ 22,752$ for patients with compensated cirrhosis and $\$ 59,995$ for patients with end-stage cirrhosis [7]. The primary clinical manifestations of cirrhosis are impaired function of hepatocytes, the main cell type of the liver, and increased intrahepatic portal hypertension, often resulting in hepatocellular carcinoma [8]. Cirrhosis and its linked vascular dysfunction were long viewed as an irreversible, permanent complication, however advances in medicine suggest that stabilization or even reversal of the cirrhosis may be possible $[8,9]$.

In humans, the extent of chronic liver disease is categorized into four stages to determine the course of treatment, partly depending on which zone of the liver is damaged [8]. In the first stage, the damage will trigger inflammation of the liver tissue. This is followed by fibrotic deposition and scarring, at which point the liver is in the second stage and normal function begins to decrease. With the continued accumulation of fibrotic tissue the liver enters the third stage; normal function is permanently lost, leading to symptoms such as 
discoloration of the skin and eyes, loss of appetite, weight loss, and fatigue [10]. Cirrhosis is considered the end (fourth) stage of disease as the liver is unable to produce essential biomolecules like proteins, anticoagulants and detoxify substances, resulting in hypoproteinemia and accumulation of toxic substances in the body [11]. The associated vascular distortion causes the portal and arterial blood supply to expand into the hepatic outflow (main veins), disrupting the connection between hepatic sinusoids and the surrounding liver parenchyma and causing further injury [12]. Current treatment of cirrhosis focuses on symptom management and addressing the underlying causes. In cases of advanced liver disease in which hepatocyte loss cannot be compensated for, hepatocyte transplantation or orthotopic liver transplantation (OLT) are the only clinical options. Hepatocyte transplantation can be used to treat acute liver failure but has a low rate of successful engraftment (less than 30\%) [13]. While OLT can restore liver function and prolong the life of a patient, there are drawbacks such as donor shortages, and complications associated with lifelong administration of immunosuppressants [14].

\section{Normal liver physiology and structure}

The liver is the largest solid organ in the body and is responsible for many crucial roles associated with metabolism and filtering toxic agents. The basic functional unit of the liver, known as a lobule, consists of a hexagonal space populated by cells of the liver and supplied by the portal triad vessels [15]. Lobules are mainly composed of hepatocytes with distinct membranes which divide the liver into three major zones based on functionality: Zone I, also known as the periportal zone, which supplies oxygenated blood and nutrients to the hepatocytes. This region also plays a crucial role in the formation of bile, cholesterol and proteins. Zone II,the central part of the lobule, consisting of hepatocytes which connect Zone I and Zone II and coordinate lobule function. Lastly Zone III, which contains hepatocytes that participate in lipogenesis, glycolysis and detoxification. This zone is poorly supplied by oxygenated blood due to its location in the distal part of the portal region, rendering it particularly susceptible to ischemia during liver disease [16].

The liver is composed of four main types of cells categorized as either parenchymal, i.e., hepatocytes $(\mathrm{HCs})$, or non-parenchymal: hepatic stellate cells, Kupffer cells (KCs), and liver sinusoidal endothelial cells (LSECs), which cooperate in maintaining liver function. Hepatocytes, which constitute $70 \%$ of total liver cells, play a major role in detoxification, glycolysis, ketogenesis, lipogenesis, glucose and cytochrome P-450 synthesis, coagulation, and complement factor secretion [17-20]. Hepatocytes can also undergo some degree of self- renewal through cell proliferation [21]. Of the nonparenchymal cells, KCs account for almost one third in the liver. Kupffer cells are the resident macrophages of the liver, playing a role in hose immune defense and phagocytosis [22, 23]. Hepatic stellate cells, which compose $5 \%$ of liver cells, play a central role in the storing of vitamin A and lipids, but upon injury differentiate into myofibroblasts which contribute to scarring [24]. Lastly, LSECs, which form the largest number of liver nonparenchymal cells $(50 \%)$, isolate the underlying hepatic stellate cells from the sinusoidal lumen [25]. There are two additional cell types that may play a role in the response to chronic liver disease, although their presence in the human liver is debated. Hepatic stem cells (HSCs), which are a mesenchymal population of liver cells, respond to chronic hepatocellular damage by expressing morphogens such as Wnt and Hedgehog (Hh), and are suggested to support liver regeneration by mobilizing the hepatocellular reserve through the expression of $\beta$ catenin and hepatocyte growth factor (HGF) [26, 27]. Lastly, hepatic oval cells, which are a small subpopulation found in the periportal zone (Zone I) in mice [28]. Oval cells are thought to be bipotential, able to differentiate into hepatocytes or bile ductular cells and expressing both biliary and hepatocytic genes. Upon liver injury they are reported to interact with HSCs and secrete acidic and basic fibroblast growth factor (FGF-1 and FGF-2) and vascular endothelial growth factor (VEGF) $[3,29,30]$.

\section{Challenges for liver regeneration}

When the liver experiences acute damage, it may experience some degree of regeneration depending on the injury severity. Restoration of the liver following acute damage is mediated by the inflammatory reaction, matrix remodeling (i.e., matrix synthesis and fibrolysis), and hepatocyte proliferation. Non-parenchymal cells are also important for the response to drug toxicity and inflammation. The first phase of liver regeneration is priming, in which hepatocytes are activated in response to growth factors. Work done to characterize liver regeneration in mouse models has demonstrated that shortly after a partial hepatectomy (PH), the expression of over 100 genes in hepatocytes is increased [31]. Following this, there is activation of growth factor receptors expressed by hepatocytes such as epidermal growth factor receptor (EGFR) and c-Met. It has been demonstrated that signaling by these factors is necessary for regeneration; knocking down these genes fully abolishes the regenerative process and results in ascites and hyperammonemia in experimental animal models [32]. Studies have demonstrated that tumor necrosis factor alpha (TNF- $\alpha$ ) is also an important factor in promoting liver regeneration following $\mathrm{PH}$ [33]. After hepatectomy, 
TNF- $\alpha$ and other cytokines are upregulated in Kupffer cells [34], along with enteric-derived lipopolysaccharide (LPS) [35]. This activation requires the MyD88 adaptor protein, which is engaged in Toll-like receptor signaling pathways leading to hepatocyte proliferation [36]. Another molecule, lymphotoxin- $\alpha$ (LT- $\alpha)$, supports the activation of TNFR1 on hepatocytes; mouse models lacking TNF- $\alpha$ and LT- $\alpha$ exhibit reduced regeneration capability [37]. Cytokines such as interleukin-6 (IL-6) are also involved in liver regeneration. Elevated IL-6 serum levels are observed early after $\mathrm{PH}$ [31] which contribute to the regeneration of hepatocytes, and knocking down IL- 6 in the injured liver leads to necrosis and impaired regeneration [38]. Regeneration in IL-6-deficient mice can be rescued by treating animals with stem cell factor (SCF) [39]. Other soluble factors such as FGF and VEGF are crucial signals for angiogenesis, vasculogenesis and lymphogenesis in the liver [40, 41]. Lastly, expression of HGF in the liver has been shown to increase hepatocyte proliferation and accelerate liver regeneration [42]. Other factors that support the regeneration of hepatocytes include: Insulin-like growth factor (IGF), Wnt, Jagged, Delta and Notch, transforming growth factor- $\beta$ (TGF- $\beta$ ), activins, and bone morphogenetic proteins (BMPs) as discussed in more detail in Friederike Bohm et al. [33].

While many factors are released following liver injury that promote repair and regeneration, there are also many inhibitory factors. In animal models, the ability of the liver to regenerate is compromised in aged individuals (18-24 months compared to 5 to 10-week-old mice). Studies report that this decrease in regenerative ability in the aged liver is due to a reduction in the rate of regeneration with a lack of induction of hepatocyte proliferation factors concurrent with inhibition of cell cycle genes. Following EGF stimulation in aged mice, one group reported a $60 \%$ decline in EGF binding to hepatocytes, reduced expression of the hepatic high affinity EGF receptor, and a block between G1 and S-phases of the cell cycle all contributing to a reduction in regenerative capability [43]. Following liver injury there are also certain factors e.g., transforming growth factor- $\beta$ (TGF$\beta$ ), interleukin-1 (IL-1), interferon-gamma (IFN- $\gamma$ ), granulocyte colony-stimulating factor (G-CSF) and myeloid differentiation factor 88 (MyD88) involved in the inhibition of hepatocyte proliferation [44]. TGF- $\beta$ is the most well-characterized inhibitor of hepatocyte proliferation. Early studies show that TGF- $\beta$ is mainly secreted by non-parenchymal cells during liver regeneration, including hepatic stellate cells, KCs and platelets, to regulate the proliferation of hepatocytes in a paracrine manner $[2,45]$. A study by Hanan Saleh et al demonstrated that TGF- $\beta$ expression induced by EGF inhibits synthesis of DNA in adult rat hepatocytes in primary culture [46].
TGF- $\beta$ induces apoptosis and may be necessary for apoptosis activation or epithelial-mesenchymal hepatocyte transition in the damaged liver [47]. Recent studies have also shown that inhibiting the TGF- $\beta$ pathway with the TGF- $\beta$ type I receptor kinase inhibitor enhances hepatocyte proliferation during acute liver damage [48] and that TGF- $\beta$ derived from platelets suppresses liver regeneration after $\mathrm{PH}$ in rats [49]. Lastly, in a porcine study, the blockade of TGF- $\beta 1$ with monoclonal antibodies improved liver regeneration [50].

Due to the barriers preventing liver regeneration, alternative therapies are being explored for patients suffering from chronic liver disease and cirrhosis. Regenerative medicine strategies such as cell transplantation are currently among the most promising candidates. Advances in understanding of liver regeneration biology, stem cells, and 3D tissue engineering scaffolds have driven progress toward successful therapies [51]. For patients who have less advanced liver disease, regenerative strategies such as cell transplantation are an attractive alternative treatment that may promote recovery of liver function.

\section{Cell types for transplantation}

The field of cell transplantation has exploded in recent decades as a promising solution to restore function to tissues that are unable to regenerate. Chronic liver cirrhosis is a viable target for transplantation strategies as delivered cells may postpone the need for OLT and reduce the severity of liver damage by both replacing lost hepatocytes and stimulating the remaining hepatocytes to proliferate. The aim of regenerative medicine approaches is to increase the amount of functioning tissue available to restore lost liver function. It can be accomplished by:

(1). Promoting the survival and proliferation of existing hepatocytes.

(2). Regenerating new tissue to replace damaged cells.

(3). Create a growth-permissive environment for the survival and integration of new cells into the host.

A wide variety of cell types can be transplanted to achieve these aims, from primary hepatocytes to stem cells that must be differentiated either prior to transplantation or once in the liver. These cells can be transplanted as a 2D sheet, 3D suspension, or 3D organoid/ organized structure [52].

\section{Hepatocytes}

With the aim of restoring function to the liver, primary hepatocytes remain the first choice for liver transplantation. However, prolonged culture of primary human hepatocytes is unreliable and results in a loss of 
morphology and liver-specific function. Porcine hepatocytes, while easier to obtain, have restricted biocompatibility and may elicit an immune response. Lastly, human fetal hepatocytes, while able to withstand longer culture periods, are also difficult to obtain and carry tumourigenic potential [53]. Ongoing research is investigating methods to maintain hepatocyte phenotype in culture, such as culture on a monolayer coating of collagen, which has been demonstrated to rescue hepatocyte phenotype [54], but without similar strategies for the transplantation of hepatocytes, researchers must turn to other sources of cells.

\section{Hepatic stem/progenitor cells}

Hepatic stem/progenitor cells are self-renewing bipotent cells endogenous to the liver. They are derived from $\mathrm{Lgr}^{+}$(mouse) or $\mathrm{EpCAM}^{+}$(human) cholangiocytes and from bile duct fragments from mouse and human livers with the ability to differentiate into hepatocytes or cholangiocytes $[55,56]$. Another type of hepatic stem/progenitor cell are oval cells, identified in rodent studies and named for their oval-shaped nuclei [57]. Oval cells can be detected after induction of liver damage in models of toxin-induced injury or hepatic carcinogenesis. The source of oval cells in the liver is unknown, but is hypothesized to be billary epithelial cells [31]. While the lineage of these cells is well suited for liver transplantation, they are a rare cell type and there is no standardized protocol for their in vitro maintenance and differentiation into mature hepatocytes [58]. There are also no means of direct comparison of maturation level or phenotypic characterization of the derived hepatocytes, making it difficult to compare results between studies. During development, hepatoblast differentiation into hepatocytes is regulated by numerous chemical and biophysical factors [59]. These cues may be studied further and used as a basis to develop differentiation protocols in vitro, which is currently under study $[58,60]$.

\section{Non-hepatic stem cells}

The field of cell transplantation has employed a variety of stem cell types to restore function in many organ systems and the liver is no exception to this. Embryonic stem cells (ESCs), mesenchymal stem cells (MSCs) and human induced pluripotent stem cells (hiPSCs) are all capable of differentiating into functional hepatocyte-like cells when the appropriate biophysical and chemical cues are provided and may yield an unlimited supply of hepatocytes [61-63]. However, it is difficult to fully recapitulate all characteristics of mature hepatocytes with these sources of hepatocyte-like cells [64]. ESCs, while possessing an impressive capacity for proliferation, do not offer the same potential of personalized medicine that can be achieved with MSCs or iPSCs harvested from the patient's own body for transplantation. MSCs can be harvested from the bone marrow, adipose tissue, and umbilical cord blood and have been shown to differentiate into hepatocyte-like cells in vitro and in vivo [65]. A recent meta-analysis conducted on 14 human umbilical cord blood MSC transplantation trials (a total of 717 liver cirrhosis patients) reported that MSC transplantation was correlated with improved liver function and clinical symptoms with no severe events associated with transplantation [66]. There is a need for a reliable source of hepatocyte-like cells, which may be met with the use of hiPSCs due to their advantages over ESCs for in vitro hepatocyte differentiation and maturation [67, 68]. Hepatic progenitor cells or hepatocyte-like cells can be derived from hiPSCs or transformed directly into hepatocytes from fibroblasts [69] and show liver-specific gene expression and function both in culture and following transplantation in animal models of liver disease [70, 71]. The development of in vitro protocols result in functional, mature hepatocyte-like cells for transplantation is currently underway. It is important to note however that the somatic primary source of iPSCs can determine their ability to be directed towards a hepatocyte phenotype [72-74]. Interestingly, a recent publication reported the development of a non-human primate model of severe liver fibrosis that faithfully replicates human pathophysiology [75]. The authors transplanted hiPSC-derived hepatocyte-like cells via the portal vein using a clinically-relevant protocol and evaluated outcomes after 14 days. Although only assessed short-term, they reported albumin-positive viable cells in the interlobular connective tissue around the portal area vessels. This study lays the foundation for further use of nonhuman primates to investigate the feasibility of cell transplantation strategies that are currently limited to rodent studies.

\section{Multiple cell types}

Given that no one cell type can meet all the requirements for successful regeneration, many researchers have opted to simultaneously transplant multiple cell types. This strategy can involve the transplantation of one type that will provide liver functioning and one or more secondary types to provide paracrine support. For example, the addition of endothelial cells can improve hepatocyte function and facilitate vascularization after transplantation, as was demonstrated by $\mathrm{Du}$ et al., [62] This study encapsulated iPSC-derived endothelial cells (ECs) and hepatocytes into hydrogel fibers to mimic the in vivo spatial configuration of the liver [62]. A similar study combined primary hepatocytes and endothelial cells and found that hepatocytes exhibited higher bioactivity and liver-specific function when combined with ECs compared to culturing alone [76]. One study 
combined three cell types - hiPSC-derived hepatic progenitor cells, HUVECs (human umbilical vein endothelial cells), and MSCs - into a 3D printed scaffold with microscale hexagonal architecture to mimic a liver lobule. Although the authors found that the combination of three cell types enhanced liver-specific gene expression and hepatocyte function after 10 days in culture, they did not test their scaffold in vivo [77]. Future multi-cell type strategies such as this will need to expand their applicability for in vivo use.

\section{Biomaterials for cell transplantation to the liver}

Current cell transplantation strategies are hampered by poor post-delivery survival, a loss of supporting ECM and vasculature in liver, and difficulty in achieving maturity and incorporation into the host tissue [78]. Due to these hurdles, researchers have turned to the delivery of cells within biomaterial constructs to support transplanted cells and provide a scaffold for regeneration following transplantation (Fig. 1). Evolving scaffold manufacturing techniques has led to the development of matrices to promote liver regeneration from basic porous scaffolds to more complex organized scaffolds [79] (Table 1). Biomaterials need to at least partially re-create the main features of endogenous ECM 3D microarchitecture, stiffness, protein composition, and proangiogenic properties. Aggregation of hepatocytes is reported to be important to increase cell viability, function and long-term phenotypic stability [111]. This can be facilitated with the use of a biomaterial that can support hepatocyte aggregates in culture which can then be transplanted in vivo. The use of biomaterials also allows for the implantation of cells directly into the liver rather than through the portal vein, ensuring a higher number of cells are delivered to the site of liver regeneration [52].

\section{Biomaterial properties}

There are many biophysical factors which are important in selecting a material for cell transplantation. We have chosen here to highlight three of particular relevance for liver transplantation.

\section{Porosity}

Both the size and geometry of biomaterial pores are important for cell delivery, with porosity affecting cell adhesion, proliferation, migration and differentiation. Biomaterial porosity and pore size can be tuned by adjusting the concentration or crosslinking density, and reports in the literature generally suggest a pore size of $50-200 \mu \mathrm{m}$ for the culture of hepatocytes [52, 94]. Interconnected pores of approximately $50-70 \mu \mathrm{m}$ in an alginate/chitosan 3D scaffold resulted in higher hepatocyte-specific function than the control [112] and highly porous alginate/chitosan hydrogels with pore sizes of 100-200 $\mu \mathrm{m}$ support the growth of hepatocyte spheroids in culture [113, 114]. One study systematically tested the response of rat primary hepatocytes to pore sizes of 10,18, and $82 \mu \mathrm{m}$ using collagen foam scaffolds, finding that subcellular pore diameters resulted in cells taking on a cuboidal morphology and forming a monolayer, whereas increasing the pore size to $82 \mu \mathrm{m}$ induced cell spreading into a 3D network and increased albumin secretion [115]. In addition to hepatocyte function and viability, pore properties can influence the behaviour of other cell types. For example, angiogenesis can be influenced by pore size and porosity [116], as well as hepatic stellate cell migration on PLGA scaffolds [117].

\section{Stiffness}

Biomaterial stiffness is important for both the cells which are seeded as well as the location of transplantation. Stiffness has a direct effect on cell adhesion to the scaffold, cell aggregation, cell motility, and growth factor

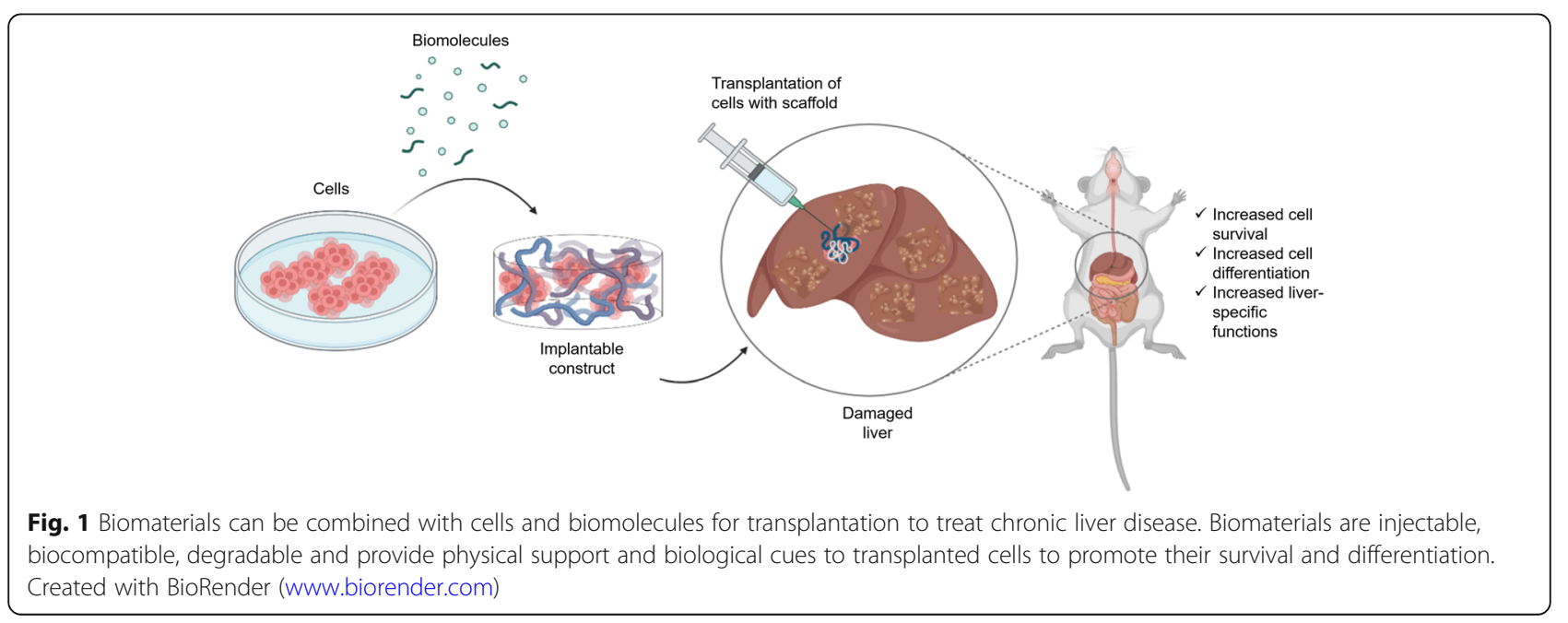


Table 1 Summary of natural and synthetic materials used to culture and deliver cells for liver

\begin{tabular}{|c|c|c|c|c|}
\hline Material & Preparation & Cell Type & Effects & Ref \\
\hline \multicolumn{5}{|c|}{ Natural Materials } \\
\hline \multirow[t]{6}{*}{ Alginate } & $\begin{array}{l}\text { Freeze drying }+ \\
\text { calcium crosslinking }\end{array}$ & Rat hepatocytes & $\begin{array}{l}\text { In vitro: increased cell viability; hepatocyte spheroid formation; } \\
\text { increased urea synthesis }\end{array}$ & \\
\hline & $\begin{array}{l}\text { Freeze drying }+ \\
\text { calcium crosslinking }\end{array}$ & $\begin{array}{l}\text { Human hepatocytes } \\
\text { and non-parenchymal } \\
\text { cells }\end{array}$ & $\begin{array}{l}\text { In vitro: expression of mature liver enzymes; albumin secretion; liver } \\
\text { organoid formation by } 6 \text { wks capable of drug metabolism }\end{array}$ & \\
\hline & $\begin{array}{l}\text { Freeze drying }+ \\
\text { calcium crosslinking }\end{array}$ & $\begin{array}{l}\text { Porcine bone marrow- } \\
\text { derived MSCs }\end{array}$ & $\begin{array}{l}\text { In vitro: expression of liver-specific genes and proteins; albumin and } \\
\text { urea production; } 56.7 \% \text { of cells expressed cytokeratin- } 18\end{array}$ & \\
\hline & $\begin{array}{l}\text { Gelation freeze } \\
\text { technique }\end{array}$ & Rat hepatocytes & $\begin{array}{l}\text { In vitro: cell viability maintained; albumin and urea production; } \\
\text { fibronectin synthesis; no cell proliferation }\end{array}$ & \\
\hline & $\begin{array}{l}\text { 3D bioprinting }+ \\
\text { calcium crosslinking }\end{array}$ & HepG2 cell line & $\begin{array}{l}\text { In vitro: liver-specific gene expression; recapitulation of lobule } \\
\text { structure }\end{array}$ & \\
\hline & $\begin{array}{l}\text { 3D bioprinting }+ \\
\text { calcium crosslinking }\end{array}$ & $\begin{array}{l}\text { Mouse embryonic } \\
\text { fibroblasts }\end{array}$ & $\begin{array}{l}\text { In vitro: formed hepatocyte-like colonies; In vivo: transplantation in } \\
\text { damaged liver expressed liver-specific markers, survived for up to } 28 \mathrm{~d}\end{array}$ & \\
\hline \multirow[t]{2}{*}{ Hyaluronate } & Photo-crosslinking & Fetal liver cells & $\begin{array}{l}\text { In vivo: regeneration of tissue; prevention of jaundice and production } \\
\text { of albumin; moderated liver fibrosis }\end{array}$ & \\
\hline & $\begin{array}{l}\text { Esterification }+ \\
\text { hydrolyzation }\end{array}$ & Mouse hepatocytes & $\begin{array}{l}\text { In vitro: established cell-cell contacts and albumin secretion in culture } \\
\text { after } 14 \mathrm{~d} \text {; In vivo: survival of transplant for } 35 \mathrm{~d}\end{array}$ & \\
\hline \multirow[t]{2}{*}{ Chitosan } & $\begin{array}{l}\text { Freeze drying }+ \\
\text { fructose addition }\end{array}$ & Mouse hepatocytes & In vitro: formation of cellular aggregates; albumin and urea secretion & \\
\hline & Electrospinning & Human hepatocytes & $\begin{array}{l}\text { In vitro: formation of aggregates, liver-specific function maintained; } \\
\text { easy detachment for downstream applications }\end{array}$ & \\
\hline \multirow[t]{3}{*}{ Collagen } & $\begin{array}{l}\text { Coated onto dextran } \\
\text { microcarriers }\end{array}$ & Rat hepatocytes & $\begin{array}{l}\text { In vivo: survival and liver-specific function in rats lacking bilirubin } \\
\text { metabolism }\end{array}$ & \\
\hline & $\begin{array}{l}\text { Coated onto } \\
\text { synthetic membrane }\end{array}$ & Porcine hepatocytes & In vitro: cell proliferation and synthesis of albumin and urea & \\
\hline & 3D bioprinting & HUH7 cell line & $\begin{array}{l}\text { In vitro: interconnected scaffold 3D geometry increased cell viability } \\
\text { and proliferation; increased liver-specific function }\end{array}$ & \\
\hline Gelatin & 3D bioprinting & Rat hepatocytes & $\begin{array}{l}\text { In vitro: viability and liver-specific functions maintained for two } \\
\text { months }\end{array}$ & \\
\hline \multirow[t]{2}{*}{ Chitosan-gelatin } & Freeze drying & $\begin{array}{l}\text { HepaRG, LSEC, and } \\
\text { HUVEC }\end{array}$ & $\begin{array}{l}\text { In vitro: HepaRG cells best viability and liver-specific function when } \\
\text { cultured with LSECs; } 3 D \text { culture improved results vs } 2 D\end{array}$ & \\
\hline & Freeze drying & Mouse hepatocytes & $\begin{array}{l}\text { In vitro: combination with alginate best albumin secretion; formation } \\
\text { of spheroids; decrease in cell viability by } 10 \mathrm{~d}\end{array}$ & \\
\hline
\end{tabular}

Cellulose Phase separation and Rat hepatocyte lyophilization

Infused into PLLA scaffold

Human iPSC-derived hepatocytes

Heparin

Photopolymerization Human ADSCs

+ lithography

Lipid conjugated + Human ADSCs coated onto cells

Natural ECM
Decellularization +3D HepG2, BMMSCs bioprinting

Decellularization + Ag nanoparticles

HepG2 and EAhy926 cell lines

$\begin{array}{ll}\text { Gelation of liver- } & \text { Primary human } \\ \text { derived ECM powder } & \text { hepatocyte } \\ \text { Decellularization } & \text { Human hepatic stem } \\ \text { (compared } 4 & \text { cells } \\ \text { methods) } & \end{array}$

In vitro: formation of hepatocyte spheroids; liver-specific functions; mature hepatocyte phenotype

In vitro: liver-specific cellular function

In vitro: increased albumin and glycogen storage; In vivo: liver retention and functional recovery

In vivo: lowered AST/ALT levels, increased hHGF, reduced inflammation, cell retention

In vitro: induced stem cell differentiation; enhanced HepG2 cell function

In vivo: proliferation and HGF expression; lower aspartate transaminase and alanine transaminase plasma levels; lower liver homogenate nitric oxide levels

In vitro: high levels of albumin expression and secretion, ammonia metabolism, and hepatic transporter expression and function

In vitro: lost stem cells markers; differentiated and maintained parenchymal phenotype for 8 wks 
Table 1 Summary of natural and synthetic materials used to culture and deliver cells for liver (Continued)

\begin{tabular}{|c|c|c|c|c|}
\hline Material & Preparation & Cell Type & Effects & Ref \\
\hline \multicolumn{5}{|c|}{ Synthetic materials } \\
\hline \multirow[t]{4}{*}{ PLLA } & $\begin{array}{l}\text { Dissolved in organic } \\
\text { solvent }\end{array}$ & Rat hepatocytes & $\begin{array}{l}\text { In vitro: formed spheroids with intercellular junctions; hepatocyte } \\
\text { morphology and function preserved }\end{array}$ & [104] \\
\hline & $\begin{array}{l}\text { Particulate leaching } \\
\text { method }\end{array}$ & Rat hepatocytes & $\begin{array}{l}\text { In vivo: } 1 \text { wk. post-implantation: improved cell survival, glycogen stor- } \\
\text { age capacity maintained }\end{array}$ & [105] \\
\hline & $\begin{array}{l}\text { 3D printing }+ \\
\text { infused collagen }\end{array}$ & $\begin{array}{l}\text { Human iPSC-derived } \\
\text { hepatocytes }\end{array}$ & $\begin{array}{l}\text { In vitro: viability; polarization; formation of bile canaliculi-like structures; } \\
\text { natural ECM superior hepatocyte-specific function compared to PLLA } \\
\text { scaffold }\end{array}$ & {$[97]$} \\
\hline & Gas foaming & $\begin{array}{l}\text { Fetal liver cells, hepatic } \\
\text { parenchymal cells }\end{array}$ & $\begin{array}{l}\text { In vitro: maintained cell viability; stimulated maturation of hepatic } \\
\text { parenchymal cells }\end{array}$ & [106] \\
\hline \multirow[t]{2}{*}{$\mathrm{PCL}$} & Electrospinning & HepG2 cell line & $\begin{array}{l}\text { In vitro: cells produced ECM; In vivo: support hepatic phenotype and } \\
\text { function }\end{array}$ & [107] \\
\hline & $\begin{array}{l}\text { 3D printing }+ \\
\text { collagen in channels }\end{array}$ & $\begin{array}{l}\text { Hepatocytes, HUVECs, } \\
\text { human lung } \\
\text { fibroblasts }\end{array}$ & $\begin{array}{l}\text { In vitro: improved survival of hepatocytes; albumin and urea secretion; } \\
\text { formation of network with non-parenchymal cells }\end{array}$ & [108] \\
\hline PCL-PLGA & $\begin{array}{l}\text { Multihead 3D } \\
\text { printing }\end{array}$ & Rat hepatocytes & In vitro: improved cell adhesion and proliferation; high viability & [109] \\
\hline PEG & Photopatterning & $\begin{array}{l}\text { Hepatocytes, Lewis } \\
\text { rats, NIH } 3 \text { T3-J2 }\end{array}$ & $\begin{array}{l}\text { In vitro: improved viability and liver-specific function over unpatterned } \\
\text { controls }\end{array}$ & [110] \\
\hline
\end{tabular}

responsiveness, as well as parenchymal and nonparenchymal interactions $[118,119]$. In the liver, stiffness increases as liver disease progresses and the tissue becomes more fibrotic; the stiffness of normal, early, and late stage fibrosis liver is $1.5-4.5 \mathrm{kPa}, 4.1-12.9 \mathrm{kPa}$, and $16.3-48 \mathrm{kPa}$, respectively [120]. Biomaterials can be tuned to match the stiffness of the healthy liver, or to the stiffness of various pathological states for in vitro study [121]. In general, hepatocyte function decreases as stiffness is increased [122], although there are some inconsistencies reported in the literature which may be due to variability in material preparation and properties. For example, increasing the stiffness of a polyelectrolyte multilayer decreased albumin production of hepatocytes, but in polyacrylamide gels, increased stiffness led to better hepatocyte function [123]. The hepatocellular responses to stiffness include cell migration, proliferation and differentiation. Culture of primary human hepatocytes evaluated at stiffnesses ranging from 600 to 4600 $\mathrm{Pa}$ using crosslinked HA scaffolds with liver ECM showed better attachment, viability and organization of actin cytoskeleton with increasing stiffness, however superior hepatocyte function was reported at $1200 \mathrm{~Pa}$ [124]. This difference could be due to the differing molecular pathways that control cellular functions and their responses to changes in stiffness. For example, hepatocyte function was tested with three stiffnesses representing normal $(4.5 \mathrm{kPa})$, early fibrosis $(19 \mathrm{kPa})$ and late fibrosis $(37 \mathrm{kPa})$ using a polyvinyl alcohol hydrogel. The researchers reported a dynamic balance of $\beta-1$ integrin and $\beta$-catenin pathway activation/deactivation that is controlled by stiffness, which modulates the cytoskeleton and thus migration of hepatocytes. Stiffness of a biomaterial can also control cellular differentiation. This was investigated using methacrylated HA hydrogels coupled with RGD peptides which are able to form a soft gel via Michael-type addition but could be stiffened by light-mediated radical crosslinking [125]. When hepatic stellate cells were cultured in this hydrogel, they reversibly assumed a myofibroblast phenotype with in situ stiffening. Inducible crosslinking biocompatible materials like this and others can be used to study the dynamic phenotype changes in response to fibrosis in liver disease. They may also be applicable to in vivo transplantation wherein low viscosity hydrogels can be injected and then crosslinked in situ to increase the stiffness to that of the normal liver in a minimally-invasive manner.

\section{Geometry}

Biomaterials can be fabricated using many different methods, such as electrospinning into nanofibers, 3D printing, freeze drying to form a scaffold, hydrogel, or microsphere formation. The resulting 3D geometry of the material will greatly influence the viability, proliferation, and function of seeded cells. For example, the thickness of nanofibers - which can be made from synthetic, natural, or self-assembling peptides - will control cell adherence and survival [126]. Nanofibers and microspheres provide increased surface area for cell adhesion [127] and can promote 3D hepatic sheet formation [128]. Hepatic lobules are roughly hexagonal in geometry, and micropatterning techniques to fabricate scaffolds that mimic the in vivo structure of hepatic lobules can be used to culture and maintain hepatocytes with other cell types prior to transplantation [129, 130]. Pore geometry is also important, as illustrated in a study by 
Lewis et al., [92] who tested varying scaffold pore geometries while keep pore size consistent using 3D printed gelatin scaffolds seeded with an undifferentiated hepatocyte cell line. Interestingly, they found that cell survival and proliferation did not differ between geometries, but that a more interconnected pore geometry allowed hepatocytes to aggregate, increasing albumin and cytochrome P450 production in vitro. Lastly, an important feature of hepatocytes is the polarization of cells which maintains junctional components and apical transporters necessary for cargo transport [131]. Polarization can be achieved using a sandwich system wherein cells are cultured on a 2D hydrogel layer with a second layer placed on top, which results in improved hepatocyte function in vitro [131, 132].

\section{Natural materials}

\section{Hyaluronic Acid (HA)}

Hyaluronic acid (HA) is a widely used natural material for cell transplantation due to its biocompatible and tunable nature. It is abundant in environments of increased cell proliferation such as embryogenesis, wound repair, and regeneration. For the liver, HA is the main component of the perisinusoidal space and combined with its high hydrophilicity to form a hydrogel, this makes HA a highly biocompatible material for liver transplantation [133]. High molecular weight HA also exhibits antiinflammatory properties in many models, a feature which may reduce the inflammation associated with liver disease and make the liver environment more hospitable to transplanted cells [134]. Furthermore, the backbone of HA contains carboxyl and hydroxyl groups that can be functionalized with other molecules for crosslinking to tune hydrogel stiffness, or the addition of pro-survival factors [135]. Numerous groups have demonstrated the efficacy of HA for the delivery of different cell types to the liver. Turner et al., grafted human hepatic stem cells in thiol-modified carboxymethyl HA scaffolds and transplanted them into a mouse model of liver injury [136]. The use of modified HA allows for the regulation of crosslinking and thus stiffness through the addition of a PEGDA (Poly (ethylene glycol) diacrylate) crosslinker. The researchers combined HA with either type III collagen or laminin and demonstrated that compared to direct or vascular injection of cells without a scaffold, the use of the HA scaffold resulted in a greater number of engrafted cells that remained localized to the liver and survived for 3 months post-transplantation [136]. A HAbased scaffold can also support the post-transplantation viability of multiple cell types and the formation of de novo vascular networks, as demonstrated when scaffolds seeded with hMSCs and rat hepatocytes were preconditioned in a bioreactor system prior to implantation [137]. Aside from hydrogels, HA has also been tested in the form of a sponge; Katsuda et al., (2010) transplanted fetal liver cells encapsulated in a HA sponge into mesenteric blood vessels of a rat model of Wilson's disease. They reported that, in addition to successful engraftment, the transplantation site of the mesentery provided a ready blood supply that supported transplanted cells, increasing albumin production, preventing jaundice, and diminishing fibrosis in treated animals [86]. One caveat that may need to be considered for future use of HA is that low molecular weight HA production is upregulated during liver fibrosis in human and mouse, promoting a pro-fibrogenic phenotype, proliferation, and invasion of hepatic stellate cells via TLR4 and CD44 signaling [138]. This suggests that although there are many benefits to the use of HA, further work is needed to characterize the host response to HA.

\section{Chitosan}

A unique bio-based polysaccharide, chitosan is obtained from N-deacetylation of chitin. It possesses antibacterial activity, mucoadhesive and analgesic properties [139], and is degraded into non-toxic byproducts which can be tuned by adjusting properties such as molecular mass and extent of deacetylation [140-142]. Due to the lack of cell binding domains and thus weak bioactivity towards cells, as a material for cell transplantation chitosan is often combined with other materials or functional molecules [52]. For example, lactose moieties can be conjugated to chitosan to promote cell attachment and tune the material mechanical properties, resulting in improved cell adhesion, biocompatibility and mechanical stability in a 3D scaffold for hepatocytes in culture [143]. Surface-galactose ligands can also be used to modify a chitosan nanofibrous scaffold. This modification slowed degradation and conferred biocompatible mechanical properties onto the material, leading to enhanced bioactivity of primary hepatocytes in vitro [89].

\section{Alginate}

Like chitosan, alginate is also a naturally-derived biocompatible polysaccharide not found in mammals. It is abundant and inexpensive, but due to its low celladhesiveness is often combined with other materials to increase tunability of its properties and support of transplanted cells [144]. For example, it can be both crosslinked to form hydrogels containing disulfide bonds which allows for cleavage under physiological reducing conditions, and combined with chitosan via surface modification for improved mechanical properties [145]. An RGD-modified-chitosan-alginate polyelectrolyte complex fibrous scaffold was demonstrated to support the delivery and survival of human MSCs in a hepatectomy rat model. Cells were first transdifferentiated into hepatocyte-like cells in vitro prior to seeding on the 
scaffold and were then implanted onto the liver. The researchers reported that transplantation in this scaffold resulted in increased cell survival, production of human albumin, and maintenance of the differentiated hepatic phenotype after 14days [146]. Alginate has also been used to fabricate microbeads to encapsulate hepatocytes for in vivo implantation. One group demonstrated that microbeads of approximately $600 \mu \mathrm{m}$ in size were able to support viability of human hepatocytes following intraperitoneal transplantation into a rat model of acute liver failure [147]. They demonstrated safety of the technique, mitigation of the severity of liver damage, and no significant immune response after 7 days compared to empty microbeads. One question not addressed by this work is whether microbeads would degrade over time, allowing migration of hepatocytes out into the tissue where they may repopulate the liver, or whether this strategy relies more on secretion of factors that promote recovery by the sequestered hepatocytes. It has been previously reported that within microcapsules, the mobility of hepatocytes is dependent on the viscosity, which will determine if hepatocytes aggregate within the capsule or are able to migrate outward [148]. In order to mimic the liver microenvironment using a 3D culture system, another group fabricated galactosylated alginate-based microcapsules for hepatocyte culture. Galactose groups are reported to improve the function of hepatocytes as they recognize galactose as a ligand. The researchers demonstrated that albumin secretion and urea synthesis of primary human hepatocytes was maintained in the microcapsule system [113].

\section{Gelatin}

Collagen, while the most abundant component of the ECM, must be used at high concentrations for sufficient stiffness to support cells, making it cost ineffective, and degradation is faster than polysaccharides and synthetic polymers, so has limited application for liver transplantation although it has been used for hepatocyte culture successfully [52, $149,150]$. However, gelatin, which is a natural component of the ECM derived from denatured type I collagen lacking the three alpha-helix structure, is often used in place of collagen [151]. Gelatin maintains the composition of collagen, is biodegradable, inexpensive and easy to fabricate into a 3D scaffold by various methods alone or in combination with other biomaterials. To date, gelatin has mainly been used as a $3 \mathrm{D}$ porous scaffold to support in vitro hepatocyte culture [152, 153]. Hou and Hsu fabricated a composite glutaraldehyde chitosan/gelatin 3D scaffold by freeze-drying a solution of the biomaterials. They were able to tune the compressive modulus and obtained pore structures similar to the liver
ECM and found that their scaffold supported hepatocyte viability and function in culture. They reported that after 1 week, cells expressed higher levels of albumin and urea when the pore size was 150-200 $\mu \mathrm{m}$ [154]. Others have combined gelatin with galactose or laminin to support the differentiation and viability of hepatocytes in culture, finding that 3D gelatin generally increases the expression of hepatocyte-specific genes and markers, as well as functional outputs such as albumin and urea levels $[155,156]$. Lastly gelatin can be combined with methacrylic anhydride to synthesize gelatin methacryloyl (GelMA). GelMA is biocompatible, degradable by MMPs, and possesses tunable mechanical properties [157]. It has been used to create 3D lobule-like tissues with hepatocytes and fibroblasts [158], as well as a 3D printed bioink for adult hepatocyte culture [159]. The ability of gelatin and its composites to support transplantation of cells into the liver and maintain the hepatocyte-specific function remains to be demonstrated.

\section{Cellulose}

Cellulose is a natural material derived from plant cell walls, abundant in nature and easily produced, and thus cost-efficient for fabrication. Cells can adhere to cellulose via hydrophilic hydroxyl moieties and specialized cellulose binding domains [160]. Cellulose is bioactive and has biomechanical properties that are compatible for liver transplantation, although it is infrequently reported in the literature for this purpose [161-163]. Cellulose has, however, been used extensively for hepatocyte culture [164166]. Madhushree et al., tested the ability of a nanofibrillar cellulose hydrogel to induce spheroid formation and differentiation of hepatic cell lines HepaRG and HepG2 [164]. They reported that without the addition of any other bioactive components the cellulose hydrogel formed a 3D scaffold in situ after injection and promoted hepatocyte spheroid formation and differentiation. One drawback of cellulose is that it cannot be degraded naturally in humans. Some bulk washout may occur, but overall a cellulose scaffold can be considered a permanent construct that cannot be replaced with regenerated native tissue. Conversely, this will provide long-term structural support that could be beneficial if combined with the delivery of cells that can perform the function of hepatocytes. There is also some evidence that cellulose may cause structural damage in the liver and steatosis (fatty liver disease) which should be carefully considered when adapting this biomaterial for cell transplantation to the liver $[167,168]$. 


\section{Fibrin}

Fibrin and its precursor fibrinogen have been used for liver cell culture and transplantation, albeit to a lesser extent than other natural materials. It has some advantages such as the potential to be harvested from the patient's blood, reducing immunogenicity [169], but when unmodified it has poor mechanical properties and rapid degradation in the body [170]. Fibrin does however play a role in coordinating hepatocyte division during liver regeneration via crosstalk through $\alpha \mathrm{V} \beta 3$ integrin, and has been shown to contribute directly to liver regeneration by driving platelet accumulation and regeneration after partial hepatectomy, making it an attractive material to combine with cell delivery $[171,172]$. Banihashemi et al, produced fibrin scaffolds that support human hepatocyte growth using fibrinogen and thrombin from plasma. Their scaffolds demonstrated good stability, allowing the culture of human hepatocytes and the formation of a liver-like tissue in vitro [173]. Fibrin has also been combined with HA to form semi-interpenetrating polymer networks to differentiate MSCs in vitro with positive results, but this combination has yet to be tested for the application of cell transplantation for the liver [174]. Future work may include the testing of fibrin as a composite scaffold with other materials to take advantage of its bioactive properties while offsetting its suboptimal mechanical properties.

\section{Heparin}

Heparin is an anticoagulant glycosaminoglycan naturally found in the blood. It contains moieties that bind to a large variety of growth factors, extending their half-lives and increasing bioactivity [98]. It is known to improve liver regeneration through mechanisms such as accelerated hepatocyte proliferation and can regulate cell growth and differentiation via the concentration of growth factors [175]. Previous work with heparin for liver regeneration has demonstrated its use for encapsulation of cells in a hydrogel scaffold, and to coat cells themselves to prolong their retention and reduce the immune response in vivo $[98,175,176]$. In a series of studies, Hwang et al. first used heparin to form micropatterned hydrogels for the in vitro differentiation of hASCs into hepatocytes and to prepare 'micropatches' that could be loaded with hASCs and injected intravenously to promote functional recovery in the liver [98]. The same authors also used lipid-conjugated heparin to coat hASCs prior to transplantation in a mouse model of acute liver failure, reporting that heparin coating increased the serum level of hepatic growth factor [99].

\section{Composite scaffolds}

A single material cannot meet all the requirements of liver regeneration so many strategies involve a combination of different materials that together can support cell transplantation and regeneration. Many scaffolds blend two different polysaccharides, or a polysaccharide with proteins. As mentioned previously, materials with low cell adhesion such as chitosan or alginate may be combined with other biomaterials such as $\mathrm{HA}$ and functionalized to increase cellular interactions [112, 145]. One example of this are porous hybrid sponges formed from galactosylated chitosan and HA for the coculture of primary hepatocytes and endothelial cells [76]. One group studied the combination of galactosylated alginate or unaltered alginate with chitosan and/or collagen I, reporting that the combination of galactosylated alginate + chitosan + collagen $I$ induced the best liver-specific function of HepG2 cells after 10 days of culture [177]. Natural components of the liver ECM can be combined with biocompatible materials from other areas of the body; combining HA and collagen I with hydroxyapatite into a porous scaffold yields higher viability and liver-specific gene expression of primary hepatocytes when cultured long-term [178]. In addition, Matrigel, a composite material derived from ECM of mouse sarcoma tumors, has been used to both culture adult hepatocytes $[179,180]$ but is hampered by concerns of batch-to-batch variability and undefined composition. Future studies may explore the combination of liver ECM components with other less conventional materials such as xyloglucan, a hemicellulose found in the primary cell wall of vascular plants, which was shown to enhance liver function of a human hepatocyte carcinoma cell line by promoting cell-matrix interactions in an in vitro 3D scaffold [181]. Another potential material is silk fibroin, obtained from Bombyx mori cocoons, which has been used extensively for regenerative applications in the nervous system, blood vessels, cartilage, and the bladder. $\mathrm{Xu}$ et al., used silk fibroin to deliver MSCs onto the surface of mouse livers with acute failure, where the cellmaterial combination stimulated neovascularization and improved liver function of animals [182] (Fig. 2).

\section{Decellularized materials}

The use of decellularized materials for liver regeneration is becoming increasingly recognized as a major strategy for cell delivery. This method involves the isolation of the ECM from tissues by removing cells and leaving the ECM intact, through protocols such as incubation in detergents, freeze/thaw cycles, and perfusion (reviewed in Gilbert et al. [183]. The remaining structure has a chemical composition and architecture that is similar to the native liver, retaining ECM signaling molecules and 

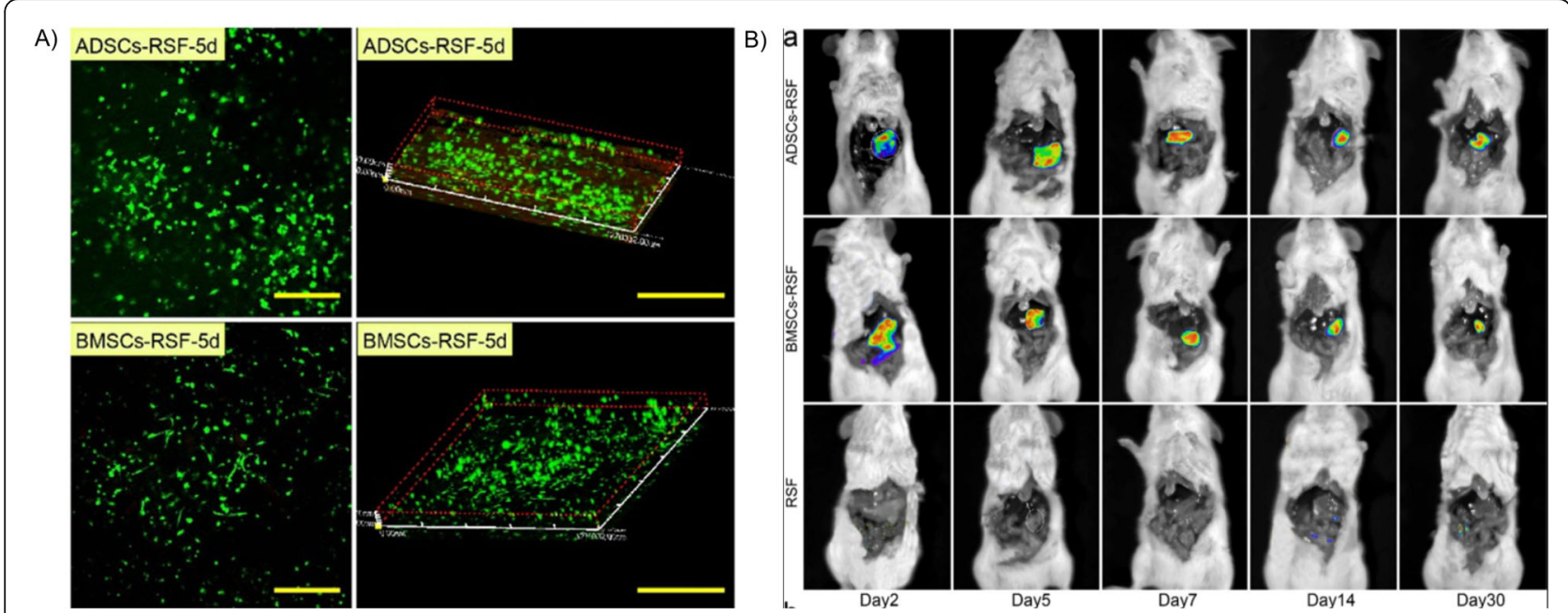

Fig. 2 Silk fibroin scaffolds provide support for adipose-derived stem cell (ADSC) and bone marrow stem cell (BMSC) survival and liver-specific function both in vitro and in vivo. a 2D and 3D light scattering confocal microscopy images of ADSCs and BMSCs (GFP, green) 5 days after encapsulation in the scaffold. Scale bar $=200 \mu \mathrm{m}$. b Fluorescence of ADSCs and BMSCs in the silk fibroin scaffolds implanted into mouse livers demonstrating cell survival up to 30 days. Adapted with permission from Ref [182]

reducing the immune response against the transplant, and can be reseeded with the desired cell type for transplantation. Whole rat livers can be decellularized and reseeded with hepatocytes and endothelial progenitor cells, as demonstrated by Zhou et al., who injected these scaffolds directly into the parenchyma via portal vein fusion, where the intact vascular structure of the artificial organ is directly connected to the circulation of the recipient [184]. Decellularized rat liver scaffolds can also promote hepatic differentiation of murine MSCs by

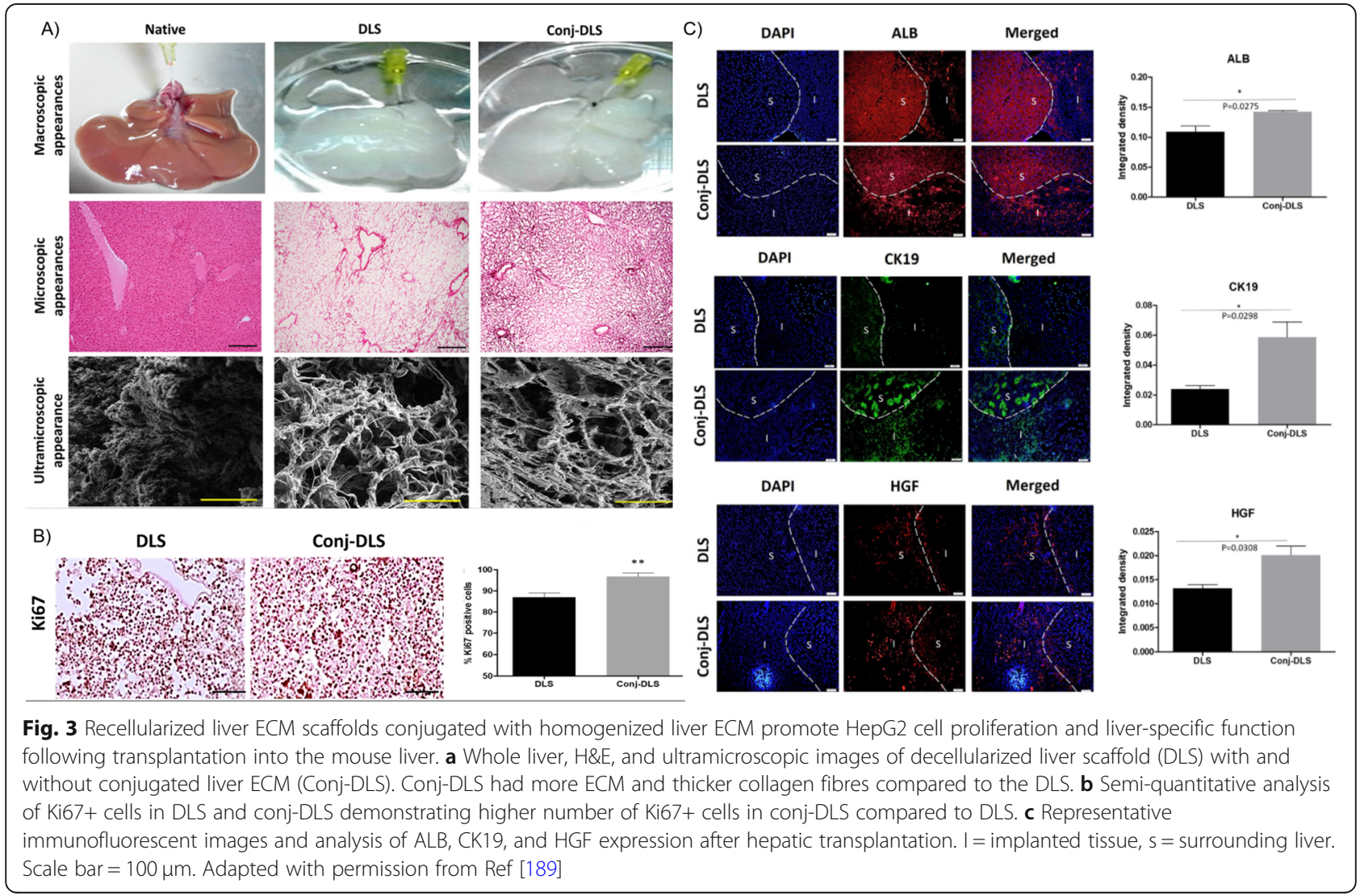


enhancing the expression of hepatocyte-specific genes and proteins [65]. Alternatively, extracts from acellular liver ECM, or whole fresh liver can be combined with natural polymers such as HA or type I collagen to form a hybrid material [185]. Skardal et al. demonstrated that customized HA hydrogels with liver-specific ECM components may be an efficient method for in vitro expansion of human hepatocytes for cell therapy or drug and toxicology screening purposes [186]. Another group adopted a similar approach by fabricating a liver ECM scaffold containing immobilized HGF and demonstrated that this scaffold could support liver-specific function of hepatocytes in culture [187]. Heparin can also be immobilized onto liver ECM scaffolds by means of layer-bylayer deposition, allowing the spatial organization of factors that can then be combined with primary rat hepatocytes that maintain albumin and urea production in vitro [188]. Future work on decellularized liver scaffolds will need to focus on improving preservation of liver ultrastructure and cell attachment. For example, a promising recent study combined homogenized liver ECM with decellularized liver scaffolds through chemical conjugation, finding that this approach improved cellular spreading, viability, and angiogenesis when the scaffold was transplanted into rat livers [189] (Fig. 3).

\section{Synthetic materials}

Synthetic materials have also been used extensively for cell transplantation to the liver. Unlike natural materials which often have poor mechanical properties, uncontrolled degradation and limited sources, synthetic polymers are readily available, have better mechanical properties, and tunable degradability. The main disadvantages of synthetic materials are the low binding affinity to cells, which can be overcome with the addition of biomolecules, and their degradation products, which may not be biocompatible [149]. Although there are multiple types of synthetic materials, we will limit our discussion here to the use of aliphatic polyesters for liver transplantation. Aliphatic polyesters, polylactic acid (PLA), polyglycolic acid (PGA), poly(E-caprolactone) (PCL), and their copolymers can be formed by polycondensation, ring opening polymerization, and enzymatic polymerization [190]. The most commonly used monomers for their synthesis in biomedical applications are lactide, glycolide and caprolactone [191]. Aliphatic polyesters contain ester bonds susceptible to hydrolysis, allowing for tunable degradability. However, many degradation products are acidic which can cause an unfavorable microenvironment for cell transplantation [192]. Despite this, these polymers have been widely used for regeneration applications in tissues such as skin, nerve, blood vessel, lung, and liver [193].

\section{Polylactic Acid (PLA) and Poly-L-lactic Acid (PLLA)}

Polylactic acid (PLA) and its derivative poly-L-lactic acid (PLLA) are copolymers that are biodegradeable and tunable over a wide range of mechanical properties. When degraded, PLA and PLLA form lactic acid monomers that are further metabolized into carbon dioxide and water. They can be formulated to be injectable and have been used extensively for clinical cosmetic implants [194]. Different methods are used to fabricate these materials into a scaffold, such as spheroid formation, gas foaming, 3D printing, and electrospinning [195]. For liver regeneration, studies have shown that PLLA scaffolds support culture of primary hepatocytes prior to transplantation and can help maintain cell morphology and function [196]. PLLA can also be combined with various factors to support hepatocyte viability and function. One study demonstrated that 3D PLLA scaffolds supported fetal liver cell culture, and that combining scaffolds with the cytokine oncostatin $\mathrm{M}$ stimulated the maturation of hepatic parenchymal cells in culture, however they did not conjugate the oncostatin $M$ directly to the PLLA scaffold [106]. Most studies report the use of PLA and PLLA in vitro, however there is evidence that they are also an effective cell vehicle for in vivo transplantation. One example combined PLA with gelatin and added bFGF to form scaffolds that promoted angiogenesis and hepatocyte survival and function after implantation into the mesentery of hepatectomized rats [105]. It is reported that injection of PLA and PLLA causes stimulation of macrophagemediated inflammation leading to erythema, swelling and bruising, which should be a consideration in future transplantation applications [197].

\section{Poly(E-caprolactone) (PCL)}

Poly(E-caprolactone) (PCL) is an FDA-approved aliphatic polymer with a semi crystalline structure and a glass transition temperature of $-60^{\circ} \mathrm{C}$, giving softness and flexibility at body temperature [133]. PCL can be fabricated for liver regeneration into a variety of scaffold types such as nanofibers and 3D porous structures [198]. Although the ability to easily control pore size and fiber orientation during fabrication gives PCL and other synthetic materials an advantage over natural biomaterials, many researchers have turned to combinations of PCL and natural materials to promote superior cell viability and function. For example, Semnani et al., combined PCL and chitosan into a nanfibrous scaffold by co-electrospinning of both materials. They were able to control pore size of the scaffold to promote mouse liver epithelial cell infiltration, PCL provided good mechanical properties to the 
scaffold, and the use of chitosan promoted cell adhesion and proliferation in vitro [199]. Another study combined PCL with natural decellularized ECM that was seeded with HepG2 cells treated with factors to promote ECM secretion [107]. They found that these hybrid scaffolds were able to support in vitro HepG2 survival and expression of liver-specific genes better than scaffolds without ECM deposition. Lastly, the biocomposite poly(L-lactic acid)-co-poly (E-caprolactone) (PLACL), formed from PLA and PCL, has been shown to promote hepatocyte differentiation from human MSCs when combined with natural materials such as collagen into a nanofibrous scaffold [200].

\section{Poly (lactic-co-glycolic) acid (PLGA)}

Poly (lactic-co-glycolic) acid is synthesized by a combination of PLA and polyglycolic acid (PGA) and like other synthetic biomaterials, it offers a similar tunability and range of mechanical properties for liver regeneration. PLGA is often combined with natural materials to form a hybrid scaffold for culture of hepatocytes, demonstrating the versatility of this material. One study used PLGA to form a patterned scaffold that was either coated with collagen or filled in with a softer 3D collagen hydrogel, into which encapsulated rat primary hepatocytes were seeded [109]. After 10 days of culture cells in the collagen

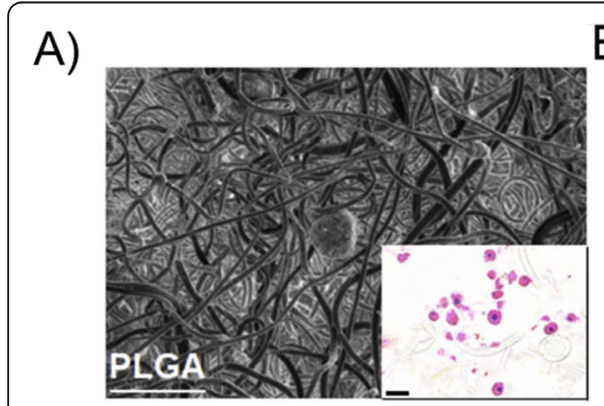

D)

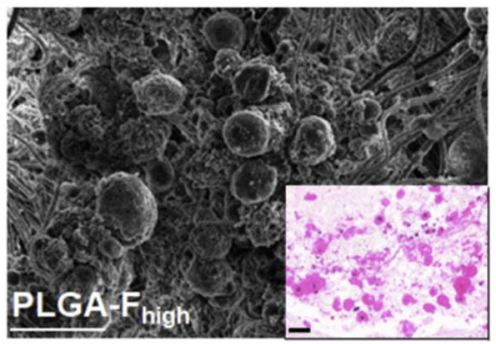

F)

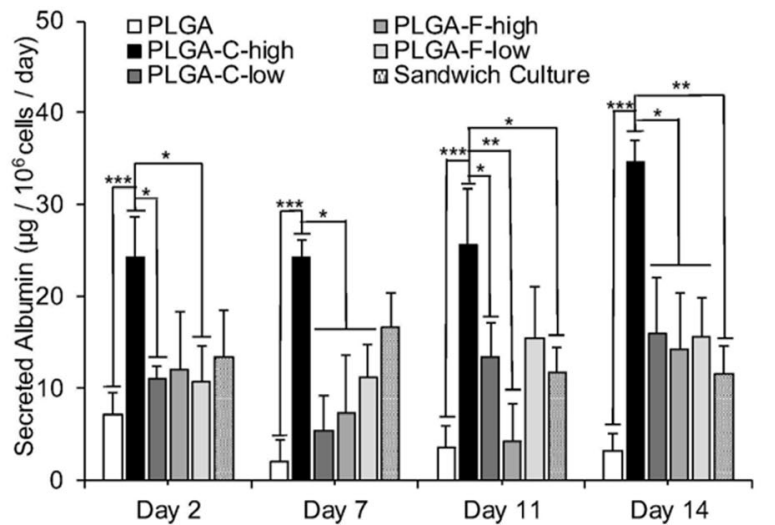

B)

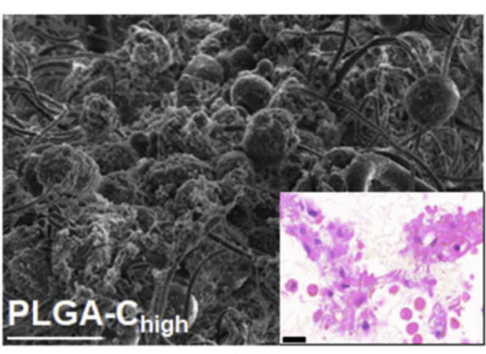

E)
C)

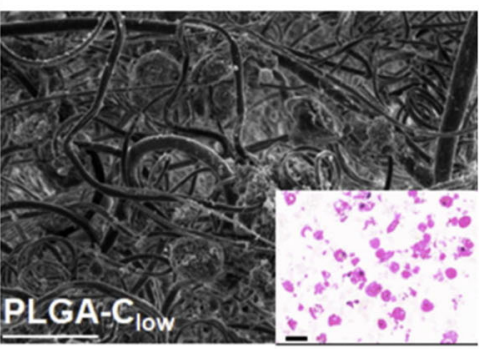

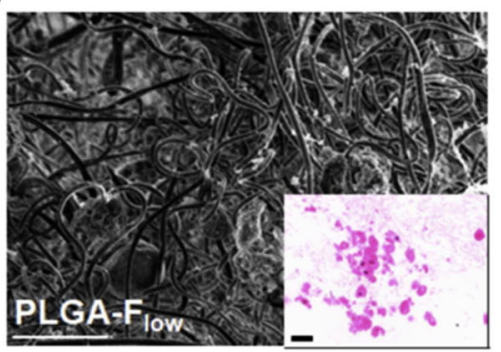

G)

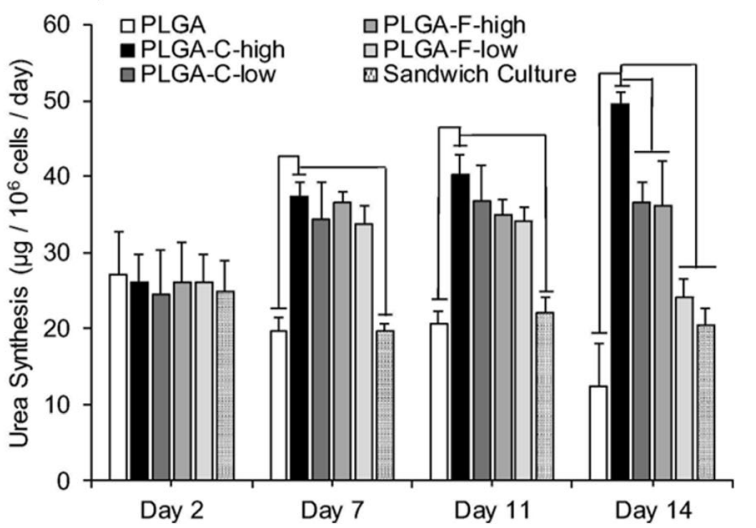

Fig. 4 Function of primary hepatocytes in electrospun PLGA scaffolds is improved with the addition of collagen 1. Scanning electron micrographs (SEM) of primary human hepatocytes within electrospun PLGA scaffolds after 14 days of culture in (a) unmodified PLGA, b PLGA with high [collagen], c PLGA with low [collagen], d PLGA with high [fibronectin] and e PLGA with low [fibronectin], scale bar = 50 $\mu$ m. Insets: representative H\&E stained hepatocytes within scaffolds, scale bar $=20 \mu \mathrm{m}$. $\mathbf{f}$ In vitro albumin secretion by hepatocytes cultured in PLGA scaffolds with/without collagen/fibronectin compared to sandwich culture. $\mathbf{g}$ In vitro urea synthesis of hepatocytes cultured in PLGA scaffolds with/ without. Adapted with permission from Ref [201] 
dispersed into 3D spaces which promoted better hepatocyte aggregation and albumin secretion than PLGA scaffolds coated with collagen. Another study directly compared the addition of fibronectin or type I collagen in a 3D nanofibrous PLGA scaffold for the culture of primary human hepatocytes, finding the best liver-specific function with the addition of type I collagen [201] (Fig. 4). As fabrication technologies such as 3D bioprinting continue to develop [202], researchers can take advantage of these methods to tailor synthetic-based scaffolds for hepatocyte culture and transplantation.

\section{Future recommendations}

The field of liver regeneration has made significant progress in the last few decades, from the design of biomaterials to culture and support hepatocyte function in vitro to their use for cell transplantation strategies in vivo. While progress has been made, there remain many hurdles to overcome to push these regenerative strategies into clinical feasibility, including improving cell viability and differentiation, supporting liver-specific function of the transplanted cells, and recapitulating the native liver environment to support cell function.

\section{Improving cell viability and differentiation}

As with any cell delivery strategy, cells need to be able to survive the delivery process and remain at the site of injury in the host environment. Due to the lack of blood supply, inflammation and fibrosis, the chronicallydiseased liver is a hostile environment for cell survival. We can take advantage of biomaterials for cell delivery to override the unsuitable environment to support cell viability, however many studies which transplant cells into the liver do not quantify cell survival. This makes it difficult to assess the effectiveness of biomaterials at supporting post-transplantation cell survival. Furthermore, transplanted cells must either be delivered as hepatocytes or be able to differentiate into hepatocyte-like cells. One study tested the ability of various culture ratios of MSCs and hepatocytes cultured in PLGA scaffolds to promote differentiation of MSCs, finding that a ratio of 1:5 MSCs to hepatocytes resulted in the best differentiation of MSCs and survival of hepatocytes. They also transplanted cell-seeded scaffolds into injured mice and reported that scaffolds promoted restoration of liver function and reduced graft rejection [70].

To support long term cell survival and differentiation into the hepatocytic lineage post-transplantation, biomaterials can be combined with soluble factors. ESCs can be differentiated into hepatocyte-like cells by applying a series of soluble factors, which has been reported using a cocktail of factors absorbed to a polyethyleneimine nanoparticle scaffold [63]. In vivo studies using this strategy are lacking. Biomaterials can also be combined with heparin to allow for binding of growth factors such as VEGF, HGF, and FGF-2 to promote cell survival and differentiation $[105,187,203]$. Aside from molecular factors, biomaterials can be functionalized with ECM proteins such as collagen and fibronectin [130]. Hepatocarcinoma cells have a different aggregation pattern when they are cultured on a PEG scaffold with proteins, suggesting that these proteins are important in cellular functioning [204]. Future studies should consider the use of these protein or factor conjugation strategies to support cell survival and differentiation for in vivo liver regeneration.

\section{Recapitulating liver tissue structure and organization}

One of the most important areas of liver regeneration that biomaterials can contribute to is reestablishment of the structure and organization of lobules. The lobule is a highly organized structure, both in terms of cell type, physical organization, and metabolically, that is difficult to restore by injection of a homogenous cell suspension. Future work with biomaterials should explore how we might mimic this organization for transplantation. There are many examples of cell-seeded scaffolds and organoids for use in vitro, but it is unknown if these constructs are suitable for the transplantation of cells. Moving forward, it is possible that multiple cell types (e.g., hepatocytes, non-paranchymal cells such as hepatic stellate cells, or endothelial cells) will need to be transplanted together, and biomaterials will need to be designed that can support both cell types [24]. Furthermore, metabolic zonation of hepatocytes is also important for maintenance of their function. McCarty et al., demonstrated this by creating controlled gradients of insulin, glucagon and 3-methylcholanthreme in a microfluidic device and culturing hepatocytes [205]. Could a strategy like this - which was designed to study drug metabolism - be translated into a viable transplantation construct?

\section{Supporting hepatocyte function}

After successful delivery of cells to the liver, cells must then perform liver-specific functions to promote regeneration. The liver is a difficult organ to regenerate because the hepatocytes are responsible for many essential but distinct functions in the body. Current studies generally use the measure of albumin and urea as indicators that transplanted cells are mature and functional. However, there is little standardization of what is adequate levels for function. Furthermore, can the level of liver functionality obtained in animal studies be translated to humans? It is possible that slight improvements in liver function in animal studies which are deemed statistically insignificant may translate to improved quality or prolongment of life for a patient with liver failure. Lastly, 
how many hepatocytes need to be replaced to see improved liver function, and what is the best way to quantify this? How many cells for delivery does this translate to? These are all important questions that will need to be tackled to move cell delivery strategies forward. Biomaterials can help to address these questions by creating microenvironments to promote hepatocyte function.

One key aspect of improving hepatocyte function is maintaining cell polarity. An interesting biomaterial design which allows this is the sandwich approach, wherein cells are cultured between two layers of a biomaterials $[131,186,201]$. One study built upon this approach by using a triple layered hepatic tissue, sandwiching a sheet of hepatocytes between two sheets of endothelial cells to mimic liver lobules [206]. They reported that cells deposited ECM between the sheets, and polarity and function of hepatocytes was maintained. The researchers suggest that the construct could be transplanted in vivo but do not demonstrate this, which highlights a commonality among studies of currently being confined to in vitro applications. Other properties of biomaterials need to be optimized to increase hepatocyte function, for example fluid shear stress and the elastic modulus [207]. Fluid shear stress is an important mechanical factor that affects hepatocyte function and phenotype by triggering mechanosensitive gene expression [208]. Normal hepatocytes are exposed to shear stress via blood flow and scaffolds designed for long-term hepatocyte culture should include this feature. Microfluidic studies have demonstrated that albumin production and urea secretion are also influenced by shear stress. Shear stress also regulates the phenotype of liver sinusoidal endothelial cells by mechanotransduction, and in the case of chronic liver disease there is an increase in ECM deposition that will confer force on resident liver cells [209]. The addition of physiological shear stress to hepatocytes prior to transplantation may increase their function and phenotypic stability after delivery. Ideally, a biomaterial would allow hepatocytes to be cultured in vitro while exposed to shear stress and could then be transplanted in the same material into the liver. Incorporating features such as cell polarity and elasticity into the biomaterial will help to increase the functionality of delivered cells to address the outstanding questions in the field.

\section{Conclusions}

Chronic liver disease and cirrhosis is a widespread and untreatable condition that leads to lifelong impairment and death. The scarcity of liver transplantation options requires the development of new strategies to attenuate disease progression and reestablish liver function by promoting regeneration. Cell transplantation is one such strategy but is hampered by the lack of a standardized cell source that can remain viable and retain liver- specific function following transplantation. Biomaterials are becoming an increasingly promising option to both culture cells for transplantation as well as to deliver cells and support their in vivo viability and long-term function. There is a wide variety of both natural and synthetic biomaterials that are now established as preclinical delivery vehicles with their own unique advantages and disadvantages for liver regeneration. Further work is needed to refine the use of these biomaterials and combine them with novel strategies that recapitulate liver organization and function in order to translate this work to clinical use.

\section{Abbreviations \\ 2D: Two dimensional; 3D: Three dimensional; BMP: Bone morphogenetic protein; CD44: Cluster of differentiation 44; EC: Endothelial cell; ECM: Extracellular matrix; EGF: Epithelial growth factor; EGFR: Epithelial growth factor receptor; EpCAM: Epithelial cellular adhesion molecule; ESC: Embryonic stem cell; FGF: Fibroblast growth factor; G-CSF: Granulocyte colony-stimulating factor; HA: Hyaluronic acid; HC: Hepatocyte; HepG2: Hepatoma G2; HGF: Hepatocyte growth factor; Hh: Hedgehog; hiPSC: Human induced pluripotent stem cell; HSC: Hepatic stem cell; HUVEC: Human umbilical vein endothelial cell; IFN- $\gamma$ : Interferon- $\gamma$; IGF: Insulin growth factor; IL: Interleukin; KC: Kupffer cell; LGR5: Leucine-rich repeat- containing G-protein coupled receptor; LPS: Lipopolysaccharide; LSEC: Liver sinusoidal endothelial cell; LT-a: Lymphotoxin-a; MSC: Mesenchymal stem cell; MyD88: Myeloid differentiation primary response 88; OLT: Orthotopic liver transplantation; PCL: Poly( $\mathcal{E}$-caprolactone); PEGDA: Poly (ethylene glycol) diacrylate; PGA: Polyglycolic acid; PH: Partial hepatectomy; PLA: Polylactic acid; PLACL: Poly(L-lactic acid)-co-poly ( $\mathcal{E}$-caprolactone); PLGA: Poly (lactic-co- glycolic acid); PLLA: Poly-L-lactic acid; SCF: Stem cell factor; TGF- $\beta$ : Transforming growth factor- $\beta$; TLR4: Toll-like receptor 4; TNFR1: Tumor necrosis factor receptor 1; TNF-a: Tumor necrosis factor-a; VEGF: Vascular endothelial growth factor; Wnt: Wingless-related integration site}

\section{Acknowledgements}

Not applicable.

\section{Authors' contributions}

MA wrote and edited figures for the manuscript. SP conceived the manuscript idea, wrote and edited the manuscript. Both authors read and approved the final manuscript.

Funding

Not applicable.

Availability of data and materials

Not applicable.

Ethics approval and consent to participate

Not applicable.

Consent for publication

Not applicable.

\section{Competing interests}

The authors declare that they have no competing interests.

\section{Author details}

'Department of Regenerative Medicine, College of Medicine,

Soonchunhyang University, Cheonan, South Korea. ${ }^{2}$ Department of Biomedical Engineering, School of Engineering, Tufts University, Medford, MA 02155, USA. 
Received: 21 December 2020 Accepted: 5 February 2021

\section{Published online: 25 February 2021}

\section{References}

1. Zou C, Ma J, Wang X, Guo L, Zhu Z, Stoops J, et al. Lack of Fas antagonism by met in human fatty liver disease. Nat Med. 2007;13(9):1078-85.

2. Fausto N, Mead JE, Braun L, Thompson NL, Panzica M, Goyette M, et al. Proto-oncogene expression and growth factors during liver regeneration. In: Symposium on Fundamental Cancer Research; 1986. p. 69-86.

3. Michalopoulos GK, Bhushan B. Liver regeneration: biological and pathological mechanisms and implications. Nat Rev Gastroenterol Hepatol. 2020:1-16.

4. Tanaka EM, Reddien PW. The cellular basis for animal regeneration. Dev Cell. 2011;21(1):172-85.

5. Tsochatzis EA, Bosch J, Burroughs AK. Liver cirrhosis. Lancet. 2014;383(9930): 1749-61 Available from: http://www.sciencedirect.com/science/article/pii/ S0140673614601215.

6. Mokdad AA, Lopez AD, Shahraz S, Lozano R, Mokdad AH, Stanaway J, et al. Liver cirrhosis mortality in 187 countries between 1980 and 2010: a systematic analysis. BMC Med. 2014;12(1):145. doi: https://doi.org/10.1186/ s12916-014-0145-y.

7. Menzin J, White LA, Nichols C, Deniz B. The economic burden of advanced liver disease among patients with hepatitis $C$ virus: a large state Medicaid perspective. BMC Health Serv Res. 2012;12(1):459. https://doi.org/10.1186/14 72-6963-12-459.

8. Schuppan D, Afdhal NH. Liver cirrhosis. Lancet. 2008;371(9615):838-51 Available from: http://www.sciencedirect.com/science/article/pii/S0140673 608603839.

9. Wanless IR, Nakashima E, Sherman M. Regression of human cirrhosis: morphologic features and the genesis of incomplete septal cirrhosis. Arch Pathol Lab Med. 2000;124(11):1599-607. https://doi.org/10.1043/0003-9985(2 000)124\%3C1599:ROHC\%3E2.0.CO;2

10. Rodríguez-Aguilera JR, de Vaca RP-C, Guerrero-Celis N, Velasco-Loyden G, Domínguez-López M, Recillas-Targa F, et al. Molecular and cellular aspects of cirrhosis and how an adenosine derivative could revert fibrosis. In: Liver Cirrhosis-Debates and Current Challenges. London: IntechOpen; 2019.

11. Cholongitas E, Papatheodoridis GV, Vangeli M, Terreni N, Patch D, Burroughs AK. Systematic review: the model for end-stage liver disease-should it replace child-Pugh's classification for assessing prognosis in cirrhosis? Aliment Pharmacol Ther. 2005;22(11-12):1079-89.

12. Schaffner F, Popper H. Capillarization of hepatic sinusoids in man. Gastroenterology. 1963;44(3):239-42.

13. Palakkan AA, Hay DC, PR AK, TV K, Ross JA. Liver tissue engineering and cell sources: issues and challenges. Liver Int. 2013;33(5):666-76 Available from: https://onlinelibrary.wiley.com/doi/abs/10.1111/liv.12134.

14. Collin de I'Hortet A, Takeishi K, Guzman-Lepe J, Handa K, Matsubara K, Fukumitsu K, et al. Liver-Regenerative Transplantation: Regrow and Reset. Am J Transplant. 2016;16(6):1688-96 Available from: https://onlinelibrary. wiley.com/doi/abs/10.1111/ajt.13678.

15. Sasse D, Spornitz UM, Maly IP. Liver architecture. Enzyme. 1992:46:8.

16. Bacon BR, O'Grady JG, Di Bisceglie AM, Lake JR. Comprehensive clinical hepatology. Amsterdam: Elsevier Ltd; 2006.

17. Schiff ER, Maddrey WC, Sorrell MF. Schiff's Diseases of the Liver. New Jersey: Wiley; 2011.

18. Saxena R, Theise ND, Crawford JM. Microanatomy of the human liver-exploring the hidden interfaces. Hepatology. 1999;30(6):1339-46.

19. Racanelli $V$, Rehermann B. The liver as an immunological organ. Hepatology. 2006:43(S1):S54-62.

20. Jenne CN, Kubes P. Immune surveillance by the liver. Nat Immunol. 2013; 14(10):996-1006.

21. Zhang R-R, Zheng Y-W, Li B, Nie Y-Z, Ueno Y, Tsuchida T, et al. Hepatic stem cells with self-renewal and liver repopulation potential are harbored in CDCP1-positive subpopulations of human fetal liver cells. Stem Cell Res Ther. 2018;9(1):29. https://doi.org/10.1186/s13287-017-0747-3.

22. Gao B, Jeong W, Tian Z. Liver: an organ with predominant innate immunity. Hepatology. 2008;47(2):729-36.

23. Bilzer M, Roggel F, Gerbes AL. Role of Kupffer cells in host defense and liver disease. Liver Int. 2006;26(10):1175-86.

24. Bale SS, Geerts S, Jindal R, Yarmush ML. Isolation and co-culture of rat parenchymal and non-parenchymal liver cells to evaluate cellular interactions and response. Sci Rep. 2016;6(1):25329. https://doi.org/10.1038/ srep25329.

25. DeLeve LD. Liver sinusoidal endothelial cells and liver regeneration. J Clin Invest. 2013;123(5):1861-6. https://doi.org/10.1172/JCl66025.

26. Monga SPS, Pediaditakis P, Mule K, Stolz DB, Michalopoulos GK. Changes in WNT/ß-catenin pathway during regulated growth in rat liver regeneration. Hepatology. 2001;33(5):1098-109.

27. Ochoa B, Syn W, Delgado I, Karaca GF, Jung Y, Wang J, et al. Hedgehog signaling is critical for normal liver regeneration after partial hepatectomy in mice. Hepatology. 2010;51(5):1712-23.

28. Huang J. Biology and engineering of stem cell niches. Boston: Academic Press; 2017.

29. Nagy P, Bisgaard HC, Thorgeirsson SS. Expression of hepatic transcription factors during liver development and oval cell differentiation. J Cell Biol. 1994:126(1):223-33.

30. Evarts RP, Nagy P, Nakatsukasa H, Marsden E, Thorgeirsson SS. In vivo differentiation of rat liver oval cells into hepatocytes. Cancer Res. 1989:49(6): $1541-7$

31. Fausto N, Campbell JS, Riehle KJ. Liver regeneration. Hepatology. 2006; 43(S1):S45-53 Available from: https://aasldpubs.onlinelibrary.wiley.com/doi/a bs/10.1002/hep.20969.

32. Mallet V Serpaggi J, Verkarre V, Vallet-Pichard A, Fontaine H, Pol S. GH. Brief communication: the relationship of regression of cirrhosis to outcome in chronic hepatitis C. Ann Intern Med. 2008;149(6):399-403.

33. Böhm F, Köhler UA, Speicher T, Werner S. Regulation of liver regeneration by growth factors and cytokines. EMBO Mol Med. 2010;2:294-305.

34. Yang L, Bataller R, Dulyx J, Coffman TM, Ginès P, Rippe RA, et al. Attenuated hepatic inflammation and fibrosis in angiotensin type 1a receptor deficient mice. J Hepatol. 2005;43(2):317-23 Available from: http://www.sciencedirect. com/science/article/pii/S0168827805002710.

35. Takayashiki T, Yoshidome H, Kimura F, Ohtsuka M, Shimizu Y, Kato A, et al. Increased expression of toll-like receptor 4 enhances endotoxin-induced hepatic failure in partially hepatectomized mice. J Hepatol. 2004;41(4):621-8 Available from: http://www.sciencedirect.com/science/article/pii/S016882 7804003022.

36. Seki E, Park E, Fujimoto J. Toll-like receptor signaling in liver regeneration, fibrosis and carcinogenesis. Hepatol Res. 2011;41(7):597-610 Available from: https://onlinelibrary.wiley.com/doi/abs/10.1111/j.1872-034X.2011.00822.x.

37. Knight B, Yeoh GC. TNF/LTa double knockout mice display abnormal inflammatory and regenerative responses to acute and chronic liver injury. Cell Tissue Res. 2005;319(1):61-70. https://doi.org/10.1007/s00441-004-10036.

38. Cressman DE, Greenbaum LE, DeAngelis RA, Ciliberto G, Furth EE, Poli V, et al. Liver Failure and Defective Hepatocyte Regeneration in Interleukin-6Deficient Mice. Science (80- ). 1996:274(5291):1379-83 Available from: https://science.sciencemag.org/content/sci/274/5291/1379.full.pdf.

39. Ren X, Hogaboam C, Carpenter A, Colletti L. Stem cell factor restores hepatocyte proliferation in IL-6 knockout mice following 70\% hepatectomy. J Clin Invest. 2003;112(9):1407-18. https://doi.org/10.1172/JCl17391.

40. Steiling $H$, Wüstefeld $T$, Bugnon $P$, Brauchle $M$, Fässler R, Teupser $D$, et al. Fibroblast growth factor receptor signalling is crucial for liver homeostasis and regeneration. Oncogene. 2003;22(28):4380-8. https://doi.org/10.1038/sj. onc.1206499.

41. Lohela M, Bry M, Tammela T, Alitalo K. VEGFs and receptors involved in angiogenesis versus lymphangiogenesis. Curr Opin Cell Biol. 2009:21(2):15465 Available from: http://www.sciencedirect.com/science/article/pii/ S0955067409000131.

42. Huh C-G, Factor VM, Sánchez A, Uchida K, Conner EA, Thorgeirsson SS Hepatocyte growth factor/<em $>c$-met $</$ em $>$ signaling pathway is required for efficient liver regeneration and repair. Proc Natl Acad Sci U S A. 2004; 101(13):4477-82 Available from: https://www.pnas.org/content/pnas/1 01/13/4477full.pdf.

43. Marti U. Handling of epidermal growth factor and number of epidermal growth factor receptors are changed in aged male rats. Hepatology. 1993; 18(6):1432-6 Available from: https://aasldpubs.onlinelibrary.wiley.com/doi/a bs/10.1002/hep.1840180623.

44. Liu M, Chen P. Proliferation-inhibiting pathways in liver regeneration. Mol Med Rep. 2017:16(1):23-35.

45. Braun L, Mead JE, Panzica M, Mikumo R, Bell Gl, Fausto N. Transforming growth factor beta mRNA increases during liver regeneration: a possible paracrine mechanism of growth regulation. Proc Natl Acad Sci. 1988;85(5):1539-43. 
46. Saleh $\mathrm{H}$, El-Shorbagy HM. Chitosan protects liver against ischemiareperfusion injury via regulating $\mathrm{BCl}-2 / \mathrm{Bax}$, TNF- $\alpha$ and TGF- $\beta$ expression. Int J Biol Macromol. 2020;164:1565-74.

47. Gressner OA, Lahme B, Siluschek M, Rehbein K, Herrmann J, Weiskirchen R, et al. Activation of TGF- $\beta$ within cultured hepatocytes and in liver injury leads to intracrine signaling with expression of connective tissue growth factor. J Cell Mol Med. 2008;12(6b):2717-30 Available from: https:// onlinelibrary.wiley.com/doi/abs/10.1111/j.1582-4934.2008.00260.x.

48. Karkampouna S, Goumans M-J, Ten Dijke P, Dooley S, Kruithof-de JM. Inhibition of TGF $\beta$ type I receptor activity facilitates liver regeneration upon acute CCl 4 intoxication in mice. Arch Toxicol. 2016;90(2):347-57.

49. Russell WE, Coffey RJ, Ouellette AJ, Moses HL. Type beta transforming growth factor reversibly inhibits the early proliferative response to partial hepatectomy in the rat. Proc Natl Acad Sci. 1988;85(14):5126-30.

50. Liska V, Treska V, Mirka H, Kobr J, Sykora R, Skalicky T, et al. Inhibition of transforming growth factor beta-1 augments liver regeneration after partial portal vein ligation in a porcine experimental model. Hepatogastroenterology. 2012;59(113):235-40.

51. Bizzaro D, Burra P. RFP. New Perspectives in Liver Transplantation: From Regeneration to Bioengineering. Bioengineering. 2019;6(3):81.

52. da Silva MA, Vieira S, Zhao X, Mao Z, Gao C, Oliveira JM, et al. Advanced Biomaterials and Processing Methods for Liver Regeneration: State-of-theArt and Future Trends. Adv Healthc Mater. 2020;9(5):1901435 Available from: https://onlinelibrary.wiley.com/doi/abs/10.1002/adhm.201901435.

53. Zhang J, Zhao X, Liang L, Li J, Demirci U, Wang S. A decade of progress in liver regenerative medicine. Biomaterials. 2018;157:161-76 Available from: http://www.sciencedirect.com/science/article/pii/S0142961217307536.

54. Godoy P, Hengstler JG, Ilkavets I, Meyer C, Bachmann A, Müller A, et al. Extracellular matrix modulates sensitivity of hepatocytes to fibroblastoid dedifferentiation and transforming growth factor $\beta$-induced apoptosis. Hepatology. 2009;49(6):2031-43 Available from: https://aasldpubs.onlinelibra ry.wiley.com/doi/abs/10.1002/hep.22880

55. Huch M, Dorrell C, Boj SF, van Es JH, Li VSW, van de Wetering M, et al. In vitro expansion of single Lgr5+ liver stem cells induced by Wnt-driven regeneration. Nature. 2013;494(7436):247-50. https://doi.org/10.1038/na ture11826.

56. Huch M, Gehart H, van Boxtel R, Hamer K, Blokzijl F, Verstegen MMA, et al. Long-term culture of genome-stable Bipotent stem cells from adult human liver. Cell. 2015;160(1):299-312 Available from: http://www.sciencedirect. com/science/article/pii/S0092867414015669.

57. Sadri A-R, Jeschke MG, Amini-Nik S. Advances in liver regeneration: revisiting hepatic stem/progenitor cells and their origin. Stem Cells Int. 2016;2016: 7920897. https://doi.org/10.1155/2016/7920897 Jendelova P, editor.

58. Park MR, Wong MS, Araúzo-Bravo MJ, Lee H, Nam D, Park SY, et al. Oct4 and Hnf4a-induced hepatic stem cells ameliorate chronic liver injury in liver fibrosis model. PLoS One. 2019;14(8):e0221085. https://doi.org/10.1371/ journal.pone.0221085.

59. Ober EA, Lemaigre FP. Development of the liver: insights into organ and tissue morphogenesis. J Hepatol. 2018;68(5):1049-62 Available from: http:// www.sciencedirect.com/science/article/pii/S0168827818300151.

60. Sauer V, Roy-Chowdhury N, Guha C, Roy-Chowdhury J. Induced pluripotent stem cells as a source of hepatocytes. Curr Pathobiol Rep. 2014;2(1):11-20.

61. Shi D, Zhang J, Zhou Q, Xin J, Jiang J, Jiang L, et al. Quantitative evaluation of human bone mesenchymal stem cells rescuing fulminant hepatic failure in pigs. Gut. 2017;66(5):955-64 Available from: https://gut.bmj.com/content/ gutjnl/66/5/955.full.pdf.

62. Du C, Narayanan K, Leong MF, Wan ACA. Induced pluripotent stem cellderived hepatocytes and endothelial cells in multi-component hydrogel fibers for liver tissue engineering. Biomaterials. 2014;35(23):6006-14 Available from: http://www.sciencedirect.com/science/article/pii/S0142 961214003858.

63. Zhang S, Tong W, Zheng B, Susanto TAK, Xia L, Zhang C, et al. A robust high-throughput sandwich cell-based drug screening platform. Biomaterials. 2011;32(4):1229-41 Available from: http://www.sciencedirect.com/science/a rticle/pii/S0142961210012615

64. Chen C, Soto-Gutierrez A, Baptista PM, Spee B. Biotechnology challenges to in vitro maturation of hepatic stem cells. Gastroenterology. 2018;154(5): 1258-72 Available from: http://www.sciencedirect.com/science/article/pii/ S0016508518301665.

65. Ji R, Zhang N, You N, Li Q, Liu W, Jiang N, et al. The differentiation of MSCs into functional hepatocyte-like cells in a liver biomatrix scaffold and their transplantation into liver-fibrotic mice. Biomaterials. 2012;33(35):8995-9008 Available from: http://www.sciencedirect.com/science/article/pii/S0142 961212009611.

66. Sang W, Lv B, Li K, Lu Y. Therapeutic efficacy and safety of umbilical cord mesenchymal stem cell transplantation for liver cirrhosis in Chinese population: a meta-analysis. Clin Res Hepatol Gastroenterol. 2018;42(3):193204 Available from: http://www.sciencedirect.com/science/article/pii/s221 0740117302590

67. Hannoun Z, Steichen C, Dianat N, Weber A, Dubart-Kupperschmitt A. The potential of induced pluripotent stem cell derived hepatocytes. J Hepatol. 2016;65(1):182-99 Available from: http://www.sciencedirect.com/science/a rticle/pii/S0168827816001586.

68. Rashid ST, Corbineau S, Hannan N, Marciniak SJ, Miranda E, Alexander G, et al. Modeling inherited metabolic disorders of the liver using human induced pluripotent stem cells. J Clin Invest. 2010;120(9):3127-36. https:// doi.org/10.1172/JCl43122.

69. Huang P, Zhang L, Gao Y, He Z, Yao D, Wu Z, et al. Direct reprogramming of human fibroblasts to functional and expandable hepatocytes. Cell Stem Cell. 2014;14(3):370-84 Available from: http://www.sciencedirect.com/ science/article/pii/S1934590914000046.

70. Liu M, Yang J, Hu W, Zhang S, Wang Y. Superior performance of co-cultured mesenchymal stem cells and hepatocytes in poly (lactic acid-glycolic acid) scaffolds for the treatment of acute liver failure. Biomed Mater. 2016;11(1): 15008.

71. Hay DC, Zhao D, Fletcher J, Hewitt ZA, McLean D, Urruticoechea-Uriguen A, et al. Efficient differentiation of hepatocytes from human embryonic stem cells exhibiting markers recapitulating liver development in vivo. Stem Cells. 2008;26(4):894-902 Available from: https://stemcellsjournals.onlinelibrary. wiley.com/doi/abs/10.1634/stemcells.2007-0718.

72. Gao X, Liu Y. A transcriptomic study suggesting human iPSC-derived hepatocytes potentially offer a better in vitro model of hepatotoxicity than most hepatoma cell lines. Cell Bol Toxicol. 2017;33(4):407-21. https://doi. org/10.1007/s10565-017-9383-Z

73. Raab S, Klingenstein M, Liebau S, Linta L. A comparative view on human somatic cell sources for iPSC generation. Stem Cells Int. 2014;2014:768391. https://doi.org/10.1155/2014/768391 Lyons GE, editor.

74. Yamaguchi T, Matsuzaki J, Katsuda T, Saito Y, Saito H, Ochiya T. Generation of functional human hepatocytes in vitro: current status and future prospects. Inflamm Regen. 2019;39(1):13. https://doi.org/10.1186/s41232-01 9-0102-4.

75. Yasuda K, Kotaka M, Toyohara T, Sueta S-I, Katakai Y, Ageyama N, et al. A nonhuman primate model of liver fibrosis towards cell therapy for liver cirrhosis. Biochem Biophys Res Commun. 2020;526(3):661-9 Available from: http://www.sciencedirect.com/science/article/pii/S0006291X20306434.

76. Shang Y, Tamai M, Ishii R, Nagaoka N, Yoshida Y, Ogasawara M, et al. Hybrid sponge comprised of galactosylated chitosan and hyaluronic acid mediates the co-culture of hepatocytes and endothelial cells. J Biosci Bioeng. 2014; 117(1):99-106 Available from: http://www.sciencedirect.com/science/article/ pii/S1389172313002545.

77. Ma X, Qu X, Zhu W, Li Y-S, Yuan S, Zhang H, et al. Deterministically patterned biomimetic human iPSC-derived hepatic model via rapid 3D bioprinting. Proc Natl Acad Sci. 2016;113(8):2206-11 Available from: https:// www.pnas.org/content/pnas/113/8/2206.full.pdf.

78. Nevi L, Safarikia S, Di Matteo S, Biancaniello F, Chiappetta MF, Cardinale V. Hyaluronan-based grafting strategies for liver stem cell therapy and tracking methods. Stem Cells Int. 2019;2019:3620546. https://doi.org/10.1155/2019/3 620546 Li M, editor.

79. Jain E, Damania A, Kumar A. Biomaterials for liver tissue engineering. Hepatol Int. 2014;8(2):185-97. https://doi.org/10.1007/s12072-013-9503-7.

80. Dvir-Ginzberg M, Gamlieli-Bonshtein I, Agbaria R, Cohen S. Liver tissue engineering within alginate scaffolds: effects of cell-seeding density on hepatocyte viability, morphology, and function. Tissue Eng. 2003;9(4):757-66.

81. Dvir-Ginzberg M, Elkayam T, Cohen S. Induced differentiation and maturation of newborn liver cells into functional hepatic tissue in macroporous alginate scaffolds. FASEB J. 2008;22(5):1440-9.

82. Lin N, Lin J, Bo L, Weidong $P$, Chen $S, X u$ R. Differentiation of bone marrowderived mesenchymal stem cells into hepatocyte-like cells in an alginate scaffold. Cell Prolif. 2010:43(5):427-34.

83. Glicklis R, Shapiro L, Agbaria R, Merchuk JC, Cohen S. Hepatocyte behavior within three-dimensional porous alginate scaffolds. Biotechnol Bioeng. 2000; 67(3):344-53. 
84. Jeon H, Kang K, Park SA, Kim WD, Paik SS, Lee S-H, et al. Generation of multilayered 3D structures of HepG2 cells using a bio-printing technique. Gut Liver. 2017;11(1):121.

85. Kang K, Kim Y, Jeon H, Lee SB, Kim JS, Park SA, et al. Three-dimensional bioprinting of hepatic structures with directly converted hepatocyte-like cells. Tissue Eng Part A. 2018;24(7-8):576-83.

86. Katsuda T, Teratani T, Ochiya T, Sakai Y. Transplantation of a fetal liver cellloaded hyaluronic acid sponge onto the mesentery recovers a Wilson's disease model rat. J Biochem. 2010;148(3):281-8. https://doi.org/10.1093/jb/mvq063.

87. Zavan B, Brun P, Vindigni $V$, Amadori A, Habeler W, Pontisso P, et al. Extracellular matrix-enriched polymeric scaffolds as a substrate for hepatocyte cultures: in vitro and in vivo studies. Biomaterials. 2005;26(34): 7038-45.

88. Li J, Pan J, Zhang L, Yu Y. Culture of hepatocytes on fructose-modified chitosan scaffolds. Biomaterials. 2003:24(13):2317-22.

89. Feng $Z-Q$, Chu $X$, Huang N-P, Wang T, Wang $Y$, Shi $X$, et al. The effect of nanofibrous galactosylated chitosan scaffolds on the formation of rat primary hepatocyte aggregates and the maintenance of liver function. Biomaterials. 2009;30(14):2753-63 Available from: http://www.sciencedirect. com/science/article/pii/S0142961209001124.

90. Demetriou AA, Whiting JF, Feldman D, Levenson SM, Chowdhury NR, Moscioni $A D$, et al. Replacement of liver function in rats by transplantation of microcarrier-attached hepatocytes. Science (80- ). 1986;233(4769):1190-2.

91. De Bartolo L, Jarosch-Von Schweder G, Haverich A, Bader A. A novel fullscale flat membrane bioreactor utilizing porcine hepatocytes: cell viability and tissue-specific functions. Biotechnol Prog. 2000;16(1):102-8.

92. Lewis PL, Green RM, Shah RN. 3D-printed gelatin scaffolds of differing pore geometry modulate hepatocyte function and gene expression. Acta Biomater. 2018;69:63-70 Available from: http://www.sciencedirect.com/ science/article/pii/S1742706118300011.

93. Wang X, Yan Y, Pan Y, Xiong Z, Liu H, Cheng J, et al. Generation of threedimensional hepatocyte/gelatin structures with rapid prototyping system. Tissue Eng. 2006;12(1):83-90.

94. German CL, Madihally SV. Type of endothelial cells affects HepaRG cell acetaminophen metabolism in both 2D and 3D porous scaffold cultures. J Appl Toxicol. 2019;39(3):461-72 Available from: https://onlinelibrary.wiley. com/doi/abs/10.1002/jat.3737.

95. Seo S-J, Kim I-Y, Choi Y-J, Akaike T, Cho C-S. Enhanced liver functions of hepatocytes cocultured with $\mathrm{NIH} 3 \mathrm{T3}$ in the alginate/galactosylated chitosan scaffold. Biomaterials. 2006;27(8):1487-95.

96. Nugraha B, Hong X, Mo X, Tan L, Zhang W, Chan P-M, et al. Galactosylated cellulosic sponge for multi-well drug safety testing. Biomaterials. 2011;32(29):6982-94.

97. Wang B, Jakus AE, Baptista PM, Soker S, Soto-Gutierrez A, Abecassis MM, et al. Functional maturation of induced pluripotent stem cell hepatocytes in extracellular matrix - a comparative analysis of bioartificial liver microenvironments. Stem Cells Transl Med. 2016;5(9):1257-67.

98. Hwang Y, Goh M, Kim M, Tae G. Injectable and detachable heparin-based hydrogel micropatches for hepatic differentiation of hADSCs and their liver targeted delivery. Biomaterials. 2018;165:94-104 Available from: http://www. sciencedirect.com/science/article/pii/S0142961218301601

99. Hwang Y, Kim JC, Tae G. Significantly enhanced recovery of acute liver failure by liver targeted delivery of stem cells via heparin functionalization. Biomaterials. 2019;209:67-78 Available from: http://www.sciencedirect.com/ science/article/pii/S0142961219302364.

100. Lee H, Han W, Kim H, Ha D-H, Jang J, Kim BS, et al. Development of liver decellularized extracellular matrix bioink for three-dimensional cell printingbased liver tissue engineering. Biomacromolecules. 2017;18(4):1229-37.

101. Saleh T, Ahmed E, Yu L, Hussein K, Park K-M, Lee Y-S, et al. Silver nanoparticles improve structural stability and biocompatibility of decellularized porcine liver. Artif Cells Nanomed Biotechnol. 2018;46(sup2): 273-84. https://doi.org/10.1080/21691401.2018.1457037.

102. Sellaro TL, Ranade A, Faulk DM, McCabe GP, Dorko K, Badylak SF, et al. Maintenance of human hepatocyte function in vitro by liver-derived extracellular matrix gels. Tissue Eng Part A. 2010;16(3):1075-82.

103. Wang Y, Cui C, Yamauchi M, Miguez P, Roach M, Malavarca R, et al. Lineage restriction of human hepatic stem cells to mature fates is made efficient by tissue-specific biomatrix scaffolds. Hepatology. 2011;53(1):293-305.

104. Török E, Vogel C, Lütgehetmann M, Ma PX, Dandri M, Petersen J, et al. Morphological and functional analysis of rat hepatocyte spheroids generated on poly(L-lactic acid) polymer in a pulsatile flow bioreactor. Tissue Eng. 2006;12(7):1881-90.
105. Takei T, ljima H, Sakai S, Ono T, Kawakami K. Enhanced angiogenesis in bFGFcontaining scaffold promoted viability of enclosed hepatocytes and maintained Hepatospecific glycogen storage capacity. J Chem Eng. 2005;38(11):913-7 Japan.

106. Jiang J, Kojima N, Kinoshita T, Miyajima A, Yan W, Sakai Y. Cultivation of fetal liver cells in a three-dimensional poly-L-lactic acid scaffold in the presence of Oncostatin M. Cell Transplant. 2002;11(5):403-6 Available from: https:// journals.sagepub.com/doi/abs/10.3727/000000002783985648.

107. Grant R, Hay DC, Callanan A. A Drug-Induced Hybrid Electrospun PolyCapro-Lactone: Cell-Derived Extracellular Matrix Scaffold for Liver Tissue Engineering. Tissue Eng Part A. 2017;23(13-14):650-62.

108. Lee JW, Choi Y-J, Yong W-J, Pati F, Shim J-H, Kang KS, et al. Development of a $3 \mathrm{D}$ cell printed construct considering angiogenesis for liver tissue engineering. Biofabrication. 2016;8(1):15007.

109. Shim J-H, Kim JY, Park M, Park J, Cho D-W. Development of a hybrid scaffold with synthetic biomaterials and hydrogel using solid freeform fabrication technology. Biofabrication. 2011;3(3):34102. https://doi.org/10.1 088/1758-5082/3/3/034102.

110. Tsang VL, Chen AA, Cho LM, Jadin KD, Sah RL, DeLong S, et al. Fabrication of 3D hepatic tissues by additive photopatterning of cellular hydrogels. FASEB J. 2007;21(3):790-801.

111. van Zijl F, Mikulits W. Hepatospheres: three dimensional cell cultures resemble physiological conditions of the liver. World J Hepatol. 2010;2(1):17 Available from: https://pubmed.ncbi.n/m.nih.gov/21160950.

112. Tripathi A, Tripathi A, Melo JS. Preparation of a sponge-like biocomposite agarose-chitosan scaffold with primary hepatocytes for establishing an in vitro 3D liver tissue model. RSC Adv. 2015;5(39):30701.

113. Lou R, Yu W, Song Y, Ren Y, Zheng H, Guo X, et al. Fabrication of stable galactosylated alginate microcapsules via covalent coupling onto hydroxyl groups for hepatocytes applications. Carbohydr Polym. 2017;155:456-65 Available from: http//wwww.sciencedirect.com/science/article/pii/S0144861716310505.

114. Gao C, Yang Y, Zhang Y, Qian M, Yang J. HGF gene delivering alginate/ Galactosylated chitosan sponge scaffold for three-dimensional Coculture of hepatocytes/3T3 cells. DNA Cell Biol. 2020;39(3):451-8 Available from: http:// europepmc.org/abstract/MED/31910350.

115. Ranucci CS, Kumar A, Batra SP, Moghe PV. Control of hepatocyte function on collagen foams: sizing matrix pores toward selective induction of 2-D and 3-D cellular morphogenesis. Biomaterials. 2000;21(8):783-93 Available from: http://www.sciencedirect.com/science/article/pii/S0142961299002380.

116. Kant RJ, Coulombe KLK. Integrated approaches to spatiotemporally directing angiogenesis in host and engineered tissues. Acta Biomater. 2018; 69:42-62 Available from: http://www.sciencedirect.com/science/article/pii/S1 $74270611830028 X$

117. Kasuya J, Sudo R, Mitaka T, Ikeda M, Tanishita K. Hepatic stellate cellmediated three-dimensional hepatocyte and endothelial cell triculture model. Tissue Eng Part A. 2011;17(3-4):361-70.

118. Kourouklis AP, Kaylan KB, Underhill GH. Substrate stiffness and matrix composition coordinately control the differentiation of liver progenitor cells. Biomaterials. 2016;99:82-94.

119. Zaman MH, Trapani LM, Sieminski AL, Mackellar D, Gong H, Kamm RD, et al. Migration of tumor cells in 3D matrices is governed by matrix stiffness along with cell-matrix adhesion and proteolysis. Proc Natl Acad Sci U S A. 2006;103(29):10889-94

120. Takeda T, Yasuda T, Nakayama Y, Nakaya M, Kimura M, Yamashita M, et al. Usefulness of noninvasive transient elastography for assessment of liver fibrosis stage in chronic hepatitis C. World J Gastroenterol. 2006;12(48):7768-73.

121. Mazza G, Al-Akkad W, Rombouts K, Pinzani M. Liver tissue engineering: from implantable tissue to whole organ engineering. Hepatol Commun. 2017; 2(2):131-41 Available from: https://pubmed.ncbi.nlm.nih.gov/29404520.

122. Natarajan V, Berglund EJ, Chen DX, Kidambi S. Substrate stiffness regulates primary hepatocyte functions. RSC Adv. 2015;5(99):80956-66.

123. Semler EJ, Lancin PA, Dasgupta A, Moghe PV. Engineering hepatocellular morphogenesis and function via ligand-presenting hydrogels with graded mechanical compliance. Biotechnol Bioeng. 2005;89(3):296-307.

124. Deegan DB, Zimmerman C, Skardal A, Atala A, Shupe TD. Stiffness of hyaluronic acid gels containing liver extracellular matrix supports human hepatocyte function and alters cell morphology. J Mech Behav Biomed Mater. 2015;55:87-103

125. Caliari SR, Perepelyuk M, Cosgrove BD, Tsai SJ, Lee GY, Mauck RL, et al. Stiffening hydrogels for investigating the dynamics of hepatic stellate cell mechanotransduction during myofibroblast activation. Sci Rep. 2016;6(1): 21387. https://doi.org/10.1038/srep21387. 
126. Cheng T-Y, Wu H-C, Huang M-Y, Chang W-H, Lee C-H, Wang T-W. Selfassembling functionalized nanopeptides for immediate hemostasis and accelerative liver tissue regeneration. Nanoscale. 2013;5(7):2734-44. https:// doi.org/10.1039/C3NR33710C

127. Hosseini V, Maroufi NF, Saghati S, Asadi N, Darabi M, Ahmad SNS, et al. Current progress in hepatic tissue regeneration by tissue engineering. J Transl Med. 2019;17(1):383. https://doi.org/10.1186/s12967-019-02137-6.

128. Kim MH, Kumar SK, Shirahama H, Seo J, Lee JH, Cho N-J. Phenotypic regulation of liver cells in a biofunctionalized three-dimensional hydrogel platform. Integr Biol. 2016;8(2):156-66. https://doi.org/10.1039/c5ib00269a.

129. Liu Y, Li H, Yan S, Wei J, Li X. Hepatocyte cocultures with endothelial cells and fibroblasts on micropatterned fibrous mats to promote liver-specific functions and capillary formation capabilities. Biomacromolecules. 2014; 15(3):1044-54

130. Wang $Y$, Lee J-H, Shirahama H, Seo J, Glenn JS, Cho N-J. Extracellular matrix functionalization and Huh-7.5 cell Coculture promote the hepatic differentiation of human adipose-derived mesenchymal stem cells in a 3D ICC hydrogel scaffold. ACS Biomater Sci Eng. 2016;2(12):2255-65. https://doi. org/10.1021/acsbiomaterials.6b00487.

131. Zeigerer A, Wuttke A, Marsico G, Seifert S, Kalaidzidis Y, Zerial M. Functional properties of hepatocytes in vitro are correlated with cell polarity maintenance. Exp Cell Res. 2017;350(1):242-52 Available from: http://www. sciencedirect.com/science/article/pii/S0014482716304001.

132. Dunn JCY, Yarmush ML, Koebe HG, Tompkins RG. Hepatocyte function and extracellular matrix geometry: long-term culture in a sandwich configuration. FASEB J. 1989;3(2):174-7 Available from: https://faseb. onlinelibrary.wiley.com/doi/abs/10.1096/fasebj.3.2.2914628.

133. Perez RA, Jung C-R, Kim H-W. Biomaterials and Culture Technologies for Regenerative Therapy of Liver Tissue. Adv Healthc Mater. 2017;6(2):1600791 Available from: https://onlinelibrary.wiley.com/doi/abs/10.1002/adhm.201 600791

134. Gao F, Yang CX, Mo W, Liu YW, He YQ. Hyaluronan oligosaccharides are potential stimulators to angiogenesis via RHAMM mediated signal pathway in wound healing. Clin Invest Med. 2008:31(3):E106-16.

135. Collins MN, Birkinshaw C. Hyaluronic acid based scaffolds for tissue engineering - a review. Carbohydr Polym. 2013;92(2):1262-79 Available from: http://www.sciencedirect.com/science/article/pii/S0144861712010478.

136. Turner RA, Wauthier E, Lozoya O, McClelland R, Bowsher JE, Barbier C, et al. Successful transplantation of human hepatic stem cells with restricted localization to liver using hyaluronan graftst. Hepatology. 2013;57(2):775-84 Available from: https://aasldpubs.onlinelibrary.wiley.com/doi/abs/10.1002/ hep.26065.

137. Carraro A, Buggio M, Gardin C, Tedeschi U, Ferroni L, Zavan P-B. Mesenchymal Stem Cells Increase Neo-Angiogenesis and Albumin Production in a Liver Tissue-Engineered Engraftment. Int J Mol Sci. 2016; 17(3):374 Available from: https://pubmed.ncbi.n/m.nih.gov/26985891.

138. Yang YM, Noureddin M, Liu C, Ohashi K, Kim SY, Ramnath D, et al. Hyaluronan synthase 2-mediated hyaluronan production mediates Notch1 activation and liver fibrosis. Sci Transl Med. 2019:11(496):eaat9284 Available from: https://stm.sciencemag.org/content/scitransmed/11/496/eaat9284.full. pdf.

139. Croisier $F$, Jérôme $C$. Chitosan-based biomaterials for tissue engineering. Eur Polym J. 2013;49(4):780-92 Available from: http://www.sciencedirect.com/ science/article/pii/S0014305712004181.

140. Vårum KM, Myhr MM, Hjerde RJN, Smidsrød O. In vitro degradation rates of partially N-acetylated chitosans in human serum. Carbohydr Res. 1997; 299(1):99-101 Available from: http://www.sciencedirect.com/science/article/ pii/S0008621596003321.

141. Mao JS, Zhao LG, Yin YJ, De Yao K. Structure and properties of bilayer chitosan-gelatin scaffolds. Biomaterials. 2003;24(6):1067-74 Available from: http://www.sciencedirect.com/science/article/pii/S0142961202004428.

142. Huang Y, Onyeri S, Siewe M, Moshfeghian A, Madihally SV. In vitro characterization of chitosan-gelatin scaffolds for tissue engineering. Biomaterials. 2005;26(36):7616-27 Available from: http://www.sciencedirect. com/science/article/pii/S0142961205004175.

143. Wang B, Hu Q, Wan T, Yang F, Cui L, Hu S, et al. Porous lactose-modified chitosan scaffold for liver tissue engineering: influence of galactose moieties on cell attachment and mechanical stability. Int J Polym Sci. 2016;2016: 2862738. https://doi.org/10.1155/2016/2862738 Sencadas V, editor.

144. Sakai S, Yamaguchi S, Takei T, Kawakami K. Oxidized alginate-cross-linked alginate/gelatin hydrogel fibers for fabricating tubular constructs with layered smooth muscle cells and endothelial cells in collagen gels. Biomacromolecules. 2008:9(7):2036-41. https://doi.org/10.1021/bm800286v.

145. Zhao Y, Gao S, Zhao S, Li Y, Cheng L, Li J, et al. Synthesis and characterization of disulfide-crosslinked alginate hydrogel scaffolds. Mater Sci Eng C. 2012;32(8):2153-62 Available from: http://www.sciencedirect.com/ science/article/pii/S0928493112002445.

146. Tai BCU, Du C, Gao S, Wan ACA, Ying JY. The use of a polyelectrolyte fibrous scaffold to deliver differentiated hMSCs to the liver. Biomaterials. 2010;31(1):48-57 Available from: http://www.sciencedirect.com/science/a rticle/pii/S0142961209009521.

147. Jitraruch S, Dhawan A, Hughes RD, Filippi C, Soong D, Philippeos C, et al. Alginate microencapsulated hepatocytes optimised for transplantation in acute liver failure. PLoS One. 2014;9(12):e113609. https://doi.org/10.1371/ journal.pone.0113609.

148. Ito Y, Chang TMS. In vitro Study of Multicellular Hepatocyte Spheroids Formed in Microcapsules. Artif Organs. 1992;16(4):422-7. https://doi.org/1 0.1111/j.1525-1594.1992.tb00544.x.

149. Vasanthan KS, Subramanian A, Krishnan UM, Sethuraman S. Role of biomaterials, therapeutic molecules and cells for hepatic tissue engineering Biotechnol Adv. 2012;30(3):742-52 Available from: http://www.sciencedirect. com/science/article/pii/S0734975012000067.

150. Lee JS, Cho S. Liver tissue engineering: recent advances in the development of a bio-artificial liver. Biotechnol Bioprocess Eng BBE. 2012;17(3):427-38 Available from: https://login.ezproxy.library.tufts.edu/login?url=https://www. proquest.com/docview/1018462487?accountid=14434.

151. Bello AB, Kim D, Kim D, Park H, Lee SH. Engineering and Functionalization of Gelatin Biomaterials: From Cell Culture to Medical Applications. Tissue Eng Part B Rev. 2020;26(2):164-80.

152. Ruoß M, Häussling V, Schügner F, Olde Damink LHH, Lee SML, Ge L, et al. A Standardized Collagen-Based Scaffold Improves Human Hepatocyte Shipment and Allows Metabolic Studies over 10 Days. Bioeng. 2018;5(4):119.

153. Kumari J, Karande AA, Kumar A. Combined effect of Cryogel matrix and temperature-reversible soluble-insoluble polymer for the development of in vitro human liver tissue. ACS Appl Mater Interfaces. 2016;8(1):264-77. https://doi.org/10.1021/acsami.5b08607.

154. Hou Y-T, Hsu C-C. Development of a 3D porous chitosan/gelatin liver scaffold for a bioartificial liver device. J Biosci Bioeng. 2020;129(6):741-8 Available from: http://www.sciencedirect.com/science/article/pii/S1389172319308771.

155. Hong SR, Lee YM, Akaike T. Evaluation of a galactose-carrying gelatin sponge for hepatocytes culture and transplantation. J Biomed Mater Res Part A. 2003;67A(3):733-41 Available from: https://onlinelibrary.wiley.com/ doi/abs/10.1002/jbm.a.10138.

156. Mohammadpour A, Arjmand S, Lotfi AS, Tavana H, Kabir-Salmani M. Promoting hepatogenic differentiation of human mesenchymal stem cells using a novel laminin-containing gelatin cryogel scaffold. Biochem Biophys Res Commun. 2018;507(1-4):15-21.

157. Zhu M, Wang Y, Ferracci G, Zheng J, Cho N-J, Lee BH. Gelatin methacryloyl and its hydrogels with an exceptional degree of controllability and batchto-batch consistency. Sci Rep. 2019;9(1):6863. https://doi.org/10.1038/s41 598-019-42186-x.

158. Cui J, Wang H, Shi Q, Sun T, Huang Q, Fukuda T. Multicellular Co-Culture in Three-Dimensional Gelatin Methacryloyl Hydrogels for Liver Tissue Engineering. Molecules. 2019;24(9):1762 Available from: https://www.mdpi. com/1420-3049/24/9/1762.

159. Zhuang T, Li X, Deng Q, Zhao W, Lin B, Luo Y, et al. A GelMA/DECM/ nanoclay composite biomaterial ink for printing 3D scaffolds for primary hepatocytes cultivation. Mater Lett. 2020;274:128034 Available from: http:// www.sciencedirect.com/science/article/pii/S0167577X20307394.

160. Levy I, Shoseyov O. Cellulose-binding domains: biotechnological applications. Biotechnol Adv. 2002;20(3-4):191-213.

161. Domingues RM, Gomes ME, Reis RL. The potential of cellulose nanocrystals in tissue engineering strategies. Biomacromolecules. 2014;15(7):2327-46.

162. Mohite BV, Patil SV. A novel biomaterial: bacterial cellulose and its new era applications. Biotechnol Appl Biochem. 2014;61(2):101-10 Available from: https://iubmb.onlinelibrary.wiley.com/doi/abs/10.1002/bab.1148.

163. Courtenay JC, Sharma RI, Scott JL. Recent Advances in Modified Cellulose for Tissue Culture Applications. Molecules. 2018;23(3):654 Available from: https://pubmed.ncbi.nlm.nih.gov/29538287.

164. Bhattacharya M, Malinen MM, Lauren P, Lou Y-R, Kuisma SW, Kanninen L, et al. Nanofibrillar cellulose hydrogel promotes three-dimensional liver cell 
culture. J Control Release. 2012;164(3):291-8 Available from: http://www. sciencedirect.com/science/article/pii/S0168365912005391.

165. Krüger M, Oosterhoff LA, van Wolferen ME, Schiele SA, Walther A, Geijsen N, et al. Cellulose Nanofibril Hydrogel Promotes Hepatic Differentiation of Human Liver Organoids. Adv Healthc Mater. 2020;9(6):1901658. https://doi. org/10.1002/adhm.201901658.

166. Poorna MR, Sudhindran S, Thampi MV, Mony U. Differentiation of induced pluripotent stem cells to hepatocyte-like cells on cellulose nanofibril substrate. Colloids Surf B: Biointerfaces. 2020:111466 Available from: http:// www.sciencedirect.com/science/article/pii/S0927776520308225.

167. Ren S, Cai C, Cui G, Ni Q, Jiang R, Su X, et al. High dosages of pectin and cellulose cause different degrees of damage to the livers and intestines of Pelteobagrus fulvidraco. Aquaculture. 2020;514:734445 Available from: http:// www.sciencedirect.com/science/article/pii/S0044848619305988.

168. Singh V, Yeoh BS, Chassaing B, Xiao X, Saha P, Aguilera Olvera R, et al. Dysregulated Microbial Fermentation of Soluble Fiber Induces Cholestatic Liver Cancer. Cell. 2018;175(3):679-94 e22. Available from: http://www. sciencedirect.com/science/article/pii/S0092867418311760.

169. Jockenhoevel S, Zund G, Hoerstrup SP, Chalabi K, Sachweh JS, Demircan L, et al. Fibrin gel - advantages of a new scaffold in cardiovascular tissue engineering. Eur J Cardio Thoracic Surg. 2001;19(4):424-30. https://doi.org/1 0.1016/S1010-7940(01)00624-8.

170. de la Puente $P$, Ludeña D. Cell culture in autologous fibrin scaffolds for applications in tissue engineering. Exp Cell Res. 2014;322(1):1-11 Available from: http://www.sciencedirect.com/science/article/pii/S0014482713005454.

171. Groeneveld D, Pereyra D, Veldhuis Z, Adelmeijer J, Ottens P, Kopec AK, et al. Intrahepatic fibrin (ogen) deposition drives liver regeneration after partial hepatectomy in mice and humans. Blood. 2019;133(11):1245-56. https://doi. org/10.1182/blood-2018-08-869057.

172. Beier Jl, Guo L, Ritzenthaler JD, Joshi-Barve S, Roman J, Arteel GE. Fibrinmediated integrin signaling plays a critical role in hepatic regeneration after partial hepatectomy in mice. Ann Hepatol. 2016;15(5):762-72 Available from: https://pubmed.ncbi.nlm.nih.gov/27493116.

173. Banihashemi M, Mohkam M, Safari A, Nezafat N, Negahdaripour M, Mohammadi $F$, et al. Optimization of three dimensional culturing of the HepG2 cell line in fibrin scaffold. Hepat Mon. 2015;15(3):e22731 Available from: https://pubmed.ncbi.nlm.nih.gov/25861316.

174. de Melo BAG, França CG, Dávila JL, Batista NA, Caliari-Oliveira C, d'Ávila MA, et al. Hyaluronic acid and fibrin from L-PRP form semi-IPNs with tunable properties suitable for use in regenerative medicine. Mater Sci Eng C. 2020; 109:110547 Available from: http://www.sciencedirect.com/science/article/pii/ S0928493119321034.

175. Yukawa H, Noguchi H, Oishi K, Takagi S, Hamaguchi M, Hamajima N, et al. Cell Transplantation of Adipose Tissue-Derived Stem Cells in Combination with Heparin Attenuated Acute Liver Failure in Mice. Cell Transplant. 2009; 18(5-6):611-8. https://doi.org/10.1177/096368970901805-617.

176. Hu C, Zhao L, Wu Z, Li L. Transplantation of mesenchymal stem cells and their derivatives effectively promotes liver regeneration to attenuate acetaminophen-induced liver injury. Stem Cell Res Ther. 2020;11(1):88. https://doi.org/10.1186/s13287-020-01596-9.

177. Khodabakhsh Aghdam S, Khoshfetrat AB, Rahbarghazi R, Jafarizadeh-Malmiri $\mathrm{H}$, Khaksar M. Collagen modulates functional activity of hepatic cells inside alginate-galactosylated chitosan hydrogel microcapsules. Int J Biol Macromol. 2020;156:1270-8 Available from: http://www.sciencedirect.com/ science/article/pii/S0141813019387203.

178. Finoli A, Schmelzer E, Over P, Nettleship I, Gerlach JC. Open-porous hydroxyapatite scaffolds for three-dimensional culture of human adult liver cells. Biomed Res Int. 2016;2016:6040146. https://doi.org/10.1155/2016/604 0146 Kundu SC, editor.

179. Moghe PV, Berthiaume F, Ezzell RM, Toner M, Tompkins RG, Yarmush ML. Culture matrix configuration and composition in the maintenance of hepatocyte polarity and function. Biomaterials. 1996;17(3):373-85.

180. Monga SPS, Micsenyi A, Germinaro M, Apte U, Bell A. $\beta$-Catenin regulation during matrigel-induced rat hepatocyte differentiation. Cell Tissue Res. 2006;323(1):71-9.

181. Deng X, Cao Y, Yan H, Yang J, Xiong G, Yao H, et al. Enhanced liver functions of HepG2 cells in the alginate/xyloglucan scaffold. Biotechnol Lett. 2015;37(1):235-40. https://doi.org/10.1007/s10529-014-1663-6.

182. Xu L, Wang S, Sui X, Wang Y, Su Y, Huang $L$, et al. Mesenchymal stem cellseeded regenerated silk fibroin complex matrices for liver regeneration in an animal model of acute liver failure. ACS Appl Mater Interfaces. 2017;9(17): 14716-23. https://doi.org/10.1021/acsami.7b02805.
183. Gilbert TW, Sellaro TL, Badylak SF. Decellularization of tissues and organs. Biomaterials. 2006;27(19):3675-83 Available from: http://www.sciencedirect. com/science/article/pii/S0142961206001682.

184. Zhou P, Huang Y, Guo Y, Wang L, Ling C, Guo Q, et al. Decellularization and Recellularization of rat livers with hepatocytes and endothelial progenitor cells. Artif Organs. 2016;40(3):E25-38 Available from: https://onlinelibrary. wiley.com/doi/abs/10.1111/aor.12645.

185. Shimoda H, Yagi H, Higashi H, Tajima K, Kuroda K, Abe Y, et al. Decellularized liver scaffolds promote liver regeneration after partial hepatectomy. Sci Rep. 2019;9(1):12543. https://doi.org/10.1038/s41598-019-48948-x.

186. Skardal A, Smith L, Bharadwaj S, Atala A, Soker S, Zhang Y. Tissue specific synthetic ECM hydrogels for 3-D in vitro maintenance of hepatocyte function. Biomaterials. 2012;33(18):4565-75 Available from: http://www. sciencedirect.com/science/article/pii/S0142961212003213.

187. Nakamura S, ljima H. Solubilized matrix derived from decellularized liver as a growth factor-immobilizable scaffold for hepatocyte culture. J Biosci Bioeng. 2013;116(6):746-53 Available from: http://www.sciencedirect.com/science/a rticle/pii/S1389172313002132.

188. Bruinsma BG, Kim Y, Berendsen TA, Ozer S, Yarmush ML, Uygun BE. Layerby-layer heparinization of decellularized liver matrices to reduce thrombogenicity of tissue engineered grafts. J Clin Transl Res. 2015;1 (1):4856 Available from: https://pubmed.ncbi.nlm.nih.gov/30873444.

189. Saleh T, Ahmed E, Yu L, Song S-H, Park K-M, Kwak H-H, et al. Conjugating homogenized liver-extracellular matrix into decellularized hepatic scaffold for liver tissue engineering. J Biomed Mater Res Part A. 2020;108(10):19912004 Available from: https:/onlinelibrary.wiley.com/doi/abs/10.1002/jbm.a.3 6920.

190. Rydz J, Sikorska W, Kyulavska M, Christova D. Polyester-based (bio) degradable polymers as environmentally friendly materials for sustainable development. Int J Mol Sci. 2014;16(1):564-96 Available from: https:// pubmed.ncbi.nlm.nih.gov/25551604.

191. Kellie G. Introduction to technical nonwovens. In: Kellie GBT-A in TN, editor. Woodhead Publishing Series in Textiles. Cambridge: Woodhead Publishing; 2016. p. 1-17. Available from: http://www.sciencedirect.com/science/article/ pii/B9780081005750000012

192. Hammond JS, Beckingham IJ, Shakesheff KM. Scaffolds for liver tissue engineering. Expert Rev Med Devices. 2006;3(1):21-7. https://doi.org/10.1 586/17434440.3.1.21.

193. O'Brien FJ. Biomaterials \& scaffolds for tissue engineering. Mater Today. 2011;14(3):88-95 Available from: http://www.sciencedirect.com/science/a rticle/pii/S136970211170058X.

194. Sickles CK, Gross GP. Poly-L-lactic acid. Treasure Island: StatPearls Publishing; 2019. Available from: http://europepmc.org/books/NBK507871

195. Mirdamadi ES, Kalhori D, Zakeri N, Azarpira N, Solati-Hashjin M. Liver Tissue Engineering as an Emerging Alternative for Liver Disease Treatment. Tissue Eng Part B Rev. 2020;26(2):145-63.

196. Török E, Lutgehetmann M, Bierwolf J, Melbeck S, Düllmann J, Nashan B, et al. Primary human hepatocytes on biodegradable poly(l-lactic acid) matrices: a promising model for improving transplantation efficiency with tissue engineering. Liver Transpl. 2011;17(2):104-14.

197. Zhao D, Jiang W, Wang Y, Wang C, Zhang X, Li Q, et al. Three-dimensionalprinted poly-L-lactic acid scaffolds with different pore sizes influence periosteal distraction Osteogenesis of a rabbit skull. Biomed Res Int. 2020 2020:7381391. https://doi.org/10.1155/2020/7381391 Dastjerdi R, editor.

198. Balali S, Davachi SM, Sahraeian R, Shiroud Heidari B, Seyfi J, Hejazi I. Preparation and characterization of composite blends based on Polylactic acid/Polycaprolactone and silk. Biomacromolecules. 2018;19(11):4358-69. https://doi.org/10.1021/acs.biomac.8b01254.

199. Semnani D, Naghashzargar E, Hadjianfar M, Dehghan Manshadi F, Mohammadi S, Karbasi S, et al. Evaluation of PCL/chitosan electrospun nanofibers for liver tissue engineering. Int J Polym Mater Polym Biomater. 2017;66(3):149-57. https://doi.org/10.1080/00914037.2016.1190931.

200. Bishi DK, Mathapati S, Venugopal JR, Guhathakurta S, Cherian KM, Ramakrishna $S$, et al. Trans-differentiation of human mesenchymal stem cells generates functional hepatospheres on poly(I-lactic acid)-co-poly(e-caprolactone)/ collagen nanofibrous scaffolds. J Mater Chem B. 2013;1 (32):3972-84.

201. Brown JH, Das P, DiVito MD, Ivancic D, Tan LP, Wertheim JA. Nanofibrous PLGA electrospun scaffolds modified with type I collagen influence hepatocyte function and support viability in vitro. Acta Biomater. 2018;73: 217-27 Available from: http://www.sciencedirect.com/science/article/pii/S1 742706118300795 
202. Guo T, Lim CG, Noshin M, Ringel JP, Fisher JP. 3D printing bioactive PLGA scaffolds using DMSO as a removable solvent. Bioprinting. 2018;10:e00038 Available from: http://www.sciencedirect.com/science/article/pii//S240588661 8300381.

203. Mammadov R, Mammadov B, Guler MO, Tekinay AB. Growth Factor binding on heparin mimetic peptide nanofibers. Biomacromolecules. 2012;13(10): 3311-9. https://doi.org/10.1021/bm3010897.

204. Wang Y, Kim MH, Shirahama H, Lee JH, Ng SS, Glenn JS, et al. ECM proteins in a microporous scaffold influence hepatocyte morphology, function, and gene expression. Sci Rep. 2016;6(1):37427. https://doi.org/10.1038/srep37427.

205. McCarty WJ, Usta OB, Yarmush ML. A microfabricated platform for generating physiologically-relevant hepatocyte zonation. Sci Rep. 2016;6(1): 26868. https://doi.org/10.1038/srep26868.

206. Kim K, Utoh R, Ohashi K, Kikuchi T, Okano T. Fabrication of functional 3D hepatic tissues with polarized hepatocytes by stacking endothelial cell sheets in vitro. J Tissue Eng Regen Med. 2017;1 1(7):2071-80 Available from: https://onlinelibrary.wiley.com/doi/abs/10.1002/term.2102.

207. Lee H-J, Son MJ, Ahn J, Oh SJ, Lee M, Kim A, et al. Elasticity-based development of functionally enhanced multicellular 3D liver encapsulated in hybrid hydrogel. Acta Biomater. 2017;64:67-79 Available from: http:// www.sciencedirect.com/science/article/pii/S174270611730613X.

208. Kaur S, Tripathi DM, Venugopal JR, Ramakrishna S. Advances in biomaterials for hepatic tissue engineering. Curr Opin Biomed Eng. 2020;13:190-6 Available from: http://www.sciencedirect.com/science/article/pii/S246845112 0300210.

209. Venkatesh SK, Ehman RL. Magnetic resonance Elastography of liver. Magn Reson Imaging Clin. 2014;22(3):433-46. https://doi.org/10.1016/j.mric.2014. 05.001.

\section{Publisher's Note}

Springer Nature remains neutral with regard to jurisdictional claims in published maps and institutional affiliations.

Ready to submit your research? Choose BMC and benefit from:

- fast, convenient online submission

- thorough peer review by experienced researchers in your field

- rapid publication on acceptance

- support for research data, including large and complex data types

- gold Open Access which fosters wider collaboration and increased citations

- maximum visibility for your research: over $100 \mathrm{M}$ website views per year

At $\mathrm{BMC}$, research is always in progress.

Learn more biomedcentral.com/submissions 